\title{
Identification of activity-induced Egr3-dependent genes reveals genes associated with DNA damage response and schizophrenia
}

Ketan K Marballi PhD'1, Khaled Alganem BS ${ }^{2}$, Samuel J Brunwasser BS ${ }^{3}$, Arhem Barkatullah BS ${ }^{1}$, Kimberly T Meyers $\mathrm{PhD}^{1,4}$, Janet M Campbell MA ${ }^{1}$, Robert R Mccullumsmith MD, $\mathrm{PhD}^{2,5}$, Amelia L Gallitano MD, $\mathrm{PhD}^{1}$

${ }^{1}$ Department of Basic Medical Sciences, University of Arizona College of Medicine Phoenix, Phoenix AZ, 85004

2Department of Neuroscience, College of Medicine \& Life Sciences, University of Toledo, Toledo $\mathrm{OH}, 43606$

${ }^{3}$ Medical Scientist Training Program, Washington University, Washington University School of Medicine, St. Louis, MO, 63110

${ }^{4}$ Neuroscience Graduate Program, School of Life Sciences, Arizona State University, Tempe AZ, 85287

${ }^{5}$ Neurosciences institute, ProMedica, Toledo, OH, 43606

\author{
Corresponding author: Amelia L. Gallitano, MD, PhD \\ Department of Basic Medical Sciences \\ University of Arizona, College of Medicine - Phoenix \\ Phoenix, AZ, 85004 \\ Phone: 602-827-2131 \\ Fax: 602-827-2130 \\ Email: amelia@arizona.edu
}

Running Title: Egr3 required for DNA damage and schizophrenia genes 


\begin{abstract}
Bioinformatics and network studies have identified the immediate early gene transcription factor early growth response 3 (EGR3) as a master regulator of genes differentially expressed in the brains of patients with neuropsychiatric illnesses ranging from schizophrenia and bipolar disorder to Alzheimer's disease. However, few studies have identified and validated Egr3-dependent genes in the mammalian brain. We have previously shown that Egr3 is required for stress-responsive behavior, memory, and hippocampal long-term depression in mice. To identify Egr3-dependent genes that may regulate these processes, we conducted an expression microarray on hippocampi from wildtype (WT) and Egr3-/- mice following electroconvulsive seizure (ECS), a stimulus that induces maximal expression of immediate early genes including Egr3. We identified 71 genes that were differentially expressed between WT and Egr3-/- mice one hour following ECS. Bioinformatic analyses showed that many of these are altered in schizophrenia. Ingenuity pathway analysis revealed the GADD45 (growth arrest and DNA-damage-inducible) family (Gadd45b, Gadd45g) as the leading category of differentially expressed genes. Together with differentially expressed genes in the AP-1 transcription factor family genes (Fos, Fosb), and the centromere organization protein Cenpa, these results revealed that Egr3 is required for activity-dependent expression of genes involved in the DNA damage response. Our findings implicate EGR3 as gene critical for the expression of genes that are disrupted in schizophrenia and reveal a novel requirement for EGR3 in the expression of genes involved in activity-induced DNA damage response.
\end{abstract}


Major advances in genetics and genomics over the past decade have led to identification of hundreds of genes associated with risk for neuropsychiatric illnesses such as schizophrenia, bipolar disorder, depression, and Alzheimer's disease. Many of these risk genes are shared across these disorders ${ }^{1}$, each of which is characterized by cognitive dysfunction. With the discovery of such a vast number of putative illness-influencing genes, the challenge becomes how to identify the functional relationships among them, which should provide insight into the mechanisms underlying neuropsychiatric and neurodegenerative illnesses.

A promising approach has been to define functional networks of genes that are differentially regulated in individuals affected by these illnesses, compared with controls, and then to identify the "Master Regulatory Genes" that best account for these differences in gene expression. The immediate early gene transcription factor early growth response 3 (EGR3) has emerged as such a master regulator of differentially expressed genes (DEGs) in multiple neuropsychiatric disorders including schizophrenia ${ }^{2}$, bipolar disorder ${ }^{3}$, and most recently Alzheimer's disease ${ }^{4}$. However, despite these regulatory relationships identified using bioinformatic approaches, few genes regulated by EGR3 have been validated in the brain in vivo.

One of the first EGR3 downstream target genes to be identified in the brain is activityregulated cytoskeleton-associated protein $(\operatorname{Arc})^{5}$. ARC has been implicated in risk for schizophrenia by studies of rare variants, de novo mutations, and single nucleotide polymorphism association ${ }^{6-9}$. EGR3 is also reported to upregulate glutamic acid decarboxylase A4 (GABRA4) in response to seizure ${ }^{10,11}$. Neuropathologic studies have identified dysfunction in the GABAergic system in schizophrenia and GABRA4 is an autism susceptibility gene ${ }^{12}$.

Our prior work has identified deficits in the function of N-methyl D-aspartate (NMDA) receptors in Egr3-/- mice, specifically those containing the NR2B subunit ${ }^{13}$. This indicates that Egr3 is required for function of a receptor at the center of one of the leading models of schizophrenia pathogenesis, the NMDA receptor hypofunction model of schizophrenia ${ }^{14}$. In this and other studies we found that Egr3-/- mice have deficits in stress-responsive behavior, memory, and hippocampal long-term depression, further supporting the importance of Egr3 in behavioral and electrophysiologic processes implicated in neuropsychiatric disorders and cognitive processes ${ }^{13,15}$.

Based on these findings, we hypothesized that EGR3 is a critical transcriptional regulator in a biological pathway of proteins essential for memory, synaptic plasticity, and the risk for schizophrenia ${ }^{16}$. As an immediate early gene EGR3 expression is induced in response to neuronal activity in a manner dependent upon NMDA receptor function and calcium signaling, processes implicated in schizophrenia ${ }^{17}$. EGR3 interacts in regulatory feedback loops with other EGR-family genes in the immune system, including EGR1, EGR4 and NAB2, each of which maps to GWAS loci for schizophrenia 18-20. And dysfunction in these genes leads to abnormalities in processes that are disrupted in schizophrenia, including memory, synaptic plasticity, immune function, growth factor-mediated processes, myelination, and vascularization ${ }^{13,16,21-28}$. Based on the central role of EGR3 in these critical processes, we hypothesized that genes regulated downstream of EGR3 will contribute to risk for schizophrenia and other neuropsychiatric disorders that are characterized by abnormalities in cognition, memory, and synaptic function. 
To test this hypothesis, we sought to characterize the complement of genes that require EGR3 in the hippocampus, a critical region for memory formation. We used electroconvulsive seizure (ECS) to maximally activate immediate early gene expression in the hippocampus of Egr3-/- and wildtype (WT) mice and conducted an expression microarray to identify genes differentially expressed between the genotypes one hour and two hours following the stimulus, compared to baseline unstimulated conditions. Here we show that over 71 genes are differentially expressed in the hippocampi of Eg3I- mice compared to WT controls. Numerous of these Egr3-dependent genes map to schizophrenia GWAS loci, and are abnormally expressed in the brains of patients with schizophrenia, bipolar disorder, depression, and Alzheimer's disease, supporting findings of studies indicating that EGR3 may be a master regulator of genes involved in risk for numerous neuropsychiatric disorders ${ }^{2-4}$. This approach has also revealed the novel finding that one of the major classes of genes regulated downstream of EGR3 in the hippocampus are genes involved in the DNA damage response.

Materials and Methods

Mice

Previously generated Egr3-/- mice ${ }^{29}$ were backcrossed to C57BL/6 mice for greater than 20 generations. All studies were carried out on homozygous adult progeny (Egr3-/- and wildtype (WT)) resulting from heterozygote matings and were assigned as "matched pairs" at the time of weaning. Matched pairs were subjected to identical conditions for all studies. The microarray studies, and quantitative RT-PCR validation studies, were performed on a cohort of male mice ages $6-12$ months ( $n=4$ per group). Replication studies were performed on a cohort of female mice, ages $12-15$ months ( $n=4-5$ per group). Animals were housed on a 12-hour light/dark cycle with ad libitum access to food and water. All studies were performed in accordance with the University of Arizona, Institutional Animal Care and Use Committee (IACUC). This study was carried out in accordance with the recommendations of IACUC guidelines, IACUC.

\section{Electroconvulsive Seizure and Tissue Collection}

Electroconvulsive stimulation was delivered to mice via corneal electrodes 5 min.s following application of $0.5 \%$ proparacaine hydrochloride ophthalmic solution (Akorn, Inc., Lake Forest, IL, United States). The cohort of mice used for the microarray study underwent ECS without general anesthesia. The replication cohort of mice underwent ECS following general anesthesia. Isoflurane anesthesia (VetOne, Boise, ID, United States) was administered in an enclosed chamber at a flow rate of $0.5 \mathrm{~mL} / \mathrm{min}$ in oxygen. Animals were removed from the chamber after 2 minutes of complete anesthetization, transferred to room air to recover to a level of light anesthesia, and then administered electrical stimulation of $260 \mathrm{~A}$ for $1 \mathrm{~ms}$ duration and a pulse width of 0.3 $\mathrm{mm}, 1 \mathrm{~ms}$ (Ugo Basile, Varese, Italy) via orbital electrodes. Mice were observed to undergo tonic-clonic seizure and were placed in their home cage to recover for one hour prior to sacrifice. Control animals remained in their home cages undisturbed until the time of sacrifice.

Tissue Collection and RNA Isolation

Animals were sacrificed using isoflurane overdose, followed by decapitation. The brains were removed, rinsed in ice-cold phosphate buffered saline (PBS), and hemisected 
along the central sulcus into right and left hemispheres for further studies to quantify mRNA expression. Whole hippocampi were rapidly dissected and immediately placed in RNAlater (Ambion, Waltham, MA, United States). Tissue was transferred to $1.5-\mathrm{mL}$ Eppendorf tubes, frozen on dry ice and then stored at $-80^{\circ} \mathrm{C}$. For the microarray and follow-up qRT-PCR studies, RNA was isolated using TRIzol reagent (Life Technologies, Carlsbad, CA, United States) per the manufacturer's protocol. RNA was resuspended in RNAse-free water and quantitated by spectrophotometry. RNA quality and concentration were determined using an Agilent Bioanalyzer 2100 prior to microarray analysis and reverse transcription for qRT-PCR. An aliquot of the RNA samples was sent to the Microarray Resource Center, Yale/NIH Neuroscience Microarray Center (New Haven, CT, United States) for analysis using an Illumina Mouse WG6 v3.0 expression beadchip microarray. For the replication cohort, RNA isolation was performed using TRI reagent (Sigma-Aldrich, St. Louis, MO, United States) and MagMaxTM Total RNA isolation kit (Ambion, Waltham, MA, United States) according to the manufacturer's protocol, and quantified using the NanoDrop ND-1000 spectrophotometer (Thermo Scientific, Waltham, MA, United States).

Microarray Procedure and Analysis

Gene expression analysis was performed using Illumina Mouse WG6 v3.0 expression beadchip microarray and analyzed using two independent microarray analysis methods. Data analysis and quality control was initially performed using Gene Pattern (Reich et al., 2006), with normalization using the cubic spline method under the following settings (FDR $<0.05)$ to determine significantly differentially expressed genes between the WT and Egr3-/- groups 1 hour following ECS. A parallel analysis was performed using the Illumina Genome studio 2010 software to identify DEGs using the following settings: background subtraction, quantile normalization, $p<0.05$, Illumina custom algorithm. The Illumina custom algorithm uses "Diff scores" to account for reproducibility of results, by $P$ value and the magnitude of gene expression difference represented by signal intensity between the reference and control groups ${ }^{30}$, where Diff score $=10 \times($ Egr3-/- ECS signal intensity gene $A$ - WT ECS signal intensity gene $A) \times \log _{10} P$ value, where a $P$ value $>0.05$, would correspond to a diff score of $>13$ and $<-13$. Finally, a list of common DEGs between both programs was generated. From this common DEG list, genes that showed a fold change difference of 1.4-fold or higher between the two groups and a $\mathrm{p}$ value of $<0.05$ (Table 1 ), were used for all subsequent analyses ${ }^{31}$.

Ingenuity Pathway Analysis

The 71 DEGs list was imported into IPA (Ingenuity Systems, Redwood City, CA, USA; www.ingenuity.com), and analyses were carried out using default settings with the microarray WG6 gene set as background. IPA utilizes a right tailed Fisher's exact test to calculate $p$ values that are reflective of the possibility that overlap between input data and a given process or pathway, generated by curated data from the IPA database, is nonrandom.

qRT-PCR

For qRT-PCR studies, mRNA was reverse transcribed into cDNA, as previously described ${ }^{32}$, and used as a template for qRT-PCR using FastStart SYBR Green Master mix (Roche Applied Science, Indianapolis, IN, United States) on a 7500 Fast Real-Time PCR machine (ThermoFisher Scientific, Waltham, MA, United States). Each sample was 
amplified in triplicate for the gene of interest and the housekeeping gene phosphoglycerate kinase 1 (Pgk1). Pgk1 was selected as a housekeeping gene as it showed no significant changes in gene expression across experimental groups in the microarray data. This was validated by qRT-PCR across both male and female cohorts. Fold changes in gene expression were calculated and data were plotted using the $2^{-}$ ${ }^{\Delta \mathrm{CT}}$ method ${ }^{33}$.

Statistical analysis

Details of microarray and IPA analysis statistics are described in the respective sections. For analysis of qRT-PCR data, we utilized a two-way analysis of variance (ANOVA) followed by Tukey's post hoc test using GraphPad Prism with a significance threshold of $p<0.05$.

\section{Results}

To identify candidate target genes of EGR3 we conducted an expression microarray of genes differentially expressed in the hippocampus of Egr3-/- mice compared with WT controls. Because EGR3 is an activity dependent transcription factor, we used electroconvulsive stimulation to induce a seizure, which maximally actives expression of immediate early genes in the brain ${ }^{17}$. Hippocampal RNA was isolated from Egr3-/- and WT mice under three conditions: baseline (no ECS), one hour after ECS, and two hours after ECS. This allowed us to identify genes that require Egr3 under basal conditions as well as following neuronal activity.

Figure $1 \mathrm{~A}$ shows a heatmap of the 71 genes that are differentially expressed between Egr3-/- and WT mice one hour following ECS, the timepoint with the maximum number of DEGs. Of these, 57 genes were downregulated in Egr3-/- mice, while 14 genes were upregulated in Egr3-/- mice, compared to WT mice. Table 1 lists the relative expression levels for each DEG identified at $1 \mathrm{hr}$. after ECS.

The use of three timepoints (baseline, and 1 and 2 hours after ECS) allowed us to perform cluster analyses of 84 DEGs. Supplemental Figure S1 shows four major clusters of DEGs based on the patterns of gene expression changes in WT versus Egr3-/- mice over time.

\section{Egr3-dependent genes are altered in schizophrenia studies}

Next, we tested the original hypothesis for our study, that EGR3 regulates genes that play a role a role in schizophrenia. To do this we examined the expression levels of each of the 71 genes that were differentially expressed at 1 hour following ECS in 14 published schizophrenia study datasets. These include studies of genes differentially expressed in post-mortem brains, peripheral blood, fibroblasts, and induced pluripotent stem cells, from schizophrenia patients compared with controls. Expression levels for each of the 71 DEGs were assessed in the data from each schizophrenia study and used to create a heatmap for in vivo expression (Table 2, Fig. 1B).

Supplemental Figure S2 shows the proportion of schizophrenia datasets in which each of the 71 DEGs was identified as significantly different between schizophrenia subjects and controls. All but three genes coincided with differentially expressed genes in 
schizophrenia. These findings support the hypothesis that EGR3 regulates genes that are abnormally expressed in schizophrenia.

\section{EGR3-dependent DEGs are involved in DNA damage response and behavior}

To identify the major biological pathways regulated by EGR3 in the hippocampus we conducted a canonical pathway analysis using the Ingenuity Pathway Analysis (IPA) program. The results showed that the most significantly overrepresented pathway in the DEG list was GADD45 (Growth Arrest and DNA Damage) signaling, followed by corticotropin signaling, p53, ATM and Jak/STAT signaling, respectively (Fig. 2A). A literature survey revealed that GADD45, p53, ATM and Jak/STAT pathways are all involved in DNA damage response ${ }^{34} 35,36$. In addition, we also observed that 26 genes in the DEG list have roles in the regulation of behavior (Fig. 2B). Based on these observations we chose to follow-up the microarray results with validation of genes that were relevant to DNA damage response and/or neuronal function in the context of behavior.

\section{GADD45 signaling genes require Egr3 for ECS-induced expression}

The GADD45 family consists of proteins involved in regulation of DNA repair ${ }^{37,38}$ (Fig $3 A$ ), DNA demethylation ${ }^{39}$, neurogenesis ${ }^{40}$ and response to stress ${ }^{41}$. Since GADD45 signaling was significantly overrepresented in the DEG list, we conducted follow up studies on the members of the GADD45 signaling pathway that were in our DEG list: Gadd45b and Gadd45g.

Expression microarray results showed that ECS causes $a \geq 2$-fold increase in mRNA levels of both of these genes in WT mice that was not present in Egr3-/- mice (Fig. 3B$3 C)$. For both of these genes this resulted in a significantly lower level of expression following ECS in Egr3-/- mice than in WT controls. (Table 3 lists results of ANOVAs and post-hoc comparisons for all follow-up studies.)

To validate these findings, we conducted $q R T-P C R$ on the original mRNA samples that were used to perform the microarray analysis. Since the animals used in the microarray were all male, we replicated the study in female animals to determine if the gene expression changes were sex specific.

Expression of Gadd45b validated in the mRNA samples used for the microarray (Fig. 3D). In addition, in the female validation group Gadd45b showed the same pattern of a >2-fold increase in expression following ECS in WT mice that was absent in Egr3-/- mice (Fig. 3E). For Gadd45g the microarray findings were validated in the male mRNA samples (Fig. 3F) but did not show a significant difference between genotypes in the female replication cohort (data not shown, two-way ANOVA not significant, see Table 3). These results indicate that Egr3 is required for activity-dependent upregulation of GADD45 family gene expression in the hippocampus of male mice and, in the case of Gadd45b, also in female animals.

DNA damage response gene Cenpa upregulated 12-fold by ECS, which requires EGR3 Histone H3-like centromere protein A (CENPA), a protein essential for the initial stages of centromere assembly ${ }^{42}$, was recently shown to be critical for efficient DNA repair in vivo ${ }^{43}$. Cenpa showed the greatest degree of differential expression between Egr3-/and WT mice of all the genes in the microarray dataset. This was due to a 12-fold 
upregulation of Cenpa in WT mice in response to ECS that was entirely absent in Egr3-/mice (Fig. 4Ai, Table 3). This finding was validated by qRT-PCR in male mRNAs as well in the female replication cohort, in which ECS induced a 13-fold and 15-fold increase in Cenpa expression (respectively) in WT mice with no change in expression in Egr3-/mice (Fig. 4Aii \& 4Aiii, Table 3).

\section{ECS- induced gene expression of AP1 transcription factor components Fos and Fosb is Egr3 dependent}

The Activator protein 1 (AP1) transcription factor is a dimeric transcription factor whose subunits belong to four different families of DNA-binding proteins including the Jun family, Fos family, ATF/cyclic AMP-responsive element-binding (CREB) and the musculoaponeurotic fibrosarcoma (Maf) family ${ }^{44}$. The AP-1 transcription factor components play critical roles in cancer ${ }^{45}$, immune system function ${ }^{46}$, neurite growth ${ }^{47}$ and DNA repair ${ }^{48}$. Results from the microarray showed that three AP-1 components Fos, Fosb and Jun showed ECS-induced expression WT mice that was either significantly lower, or absent, in Egr3-/- mice after ECS (Figs. 4Bi, 4Ci, Table 3). Both Fos and Fosb findings were validated in male RNA samples (Figs. 4Bii, 4Cii, Table 3) and replicated in the female cohort by qRT-PCR (Figs. 4Biii, 4Ciii, Table 3).

The initial microarray showed differential expression of Jun between Egr3-/- and WT mice. The follow-up qRT-PCR studies revealed a significant effect of genotype in the female replication cohort, but not in the male validation study. See Table 3.

ECS- mediated induction of memory regulation genes Npas4 and Nr4a2 is Egr3dependent

In addition to genes involved in DNA damage response, based on our IPA analysis results, the next category of genes that we decided to investigate further were those involved in nervous system function and regulation of behavior. Two genes, neuronal Per-Arnt-Sim domain 4 (Npas4) and nuclear receptor subfamily 4 member 2 (Nr4a2) particularly stood out due to their roles in memory and neurophysiologic processes. Npas4 is essential for excitatory to inhibitory balance in the brain ${ }^{49}$ and synapse maintenance ${ }^{50}$ and plays important roles in working memory and cognitive flexibility ${ }^{51}$. $\mathrm{Nr} 4 \mathrm{a} 2$ is required for both long-term memory and object recognition ${ }^{52}$ and hippocampal neurogenesis ${ }^{53}$ and was recently shown to be critical for DNA repair in vivo ${ }^{54}$.

In WT mice, ECS induced a 2.8 - 3-fold upregulation of both Npas4 and Nr4a2 expression that was absent in Egr3-/- mice (Figs. 4Di, 4Ei, Table 3). The results of the microarray were validated in the male RNAs and replicated in the female cohort by qRTPCR for both genes (Figs. 4Dii - iii, 4Eii - iii, Table 3).

Genes upregulated in Egr3-/- mice including Mef2c and Calb2 are linked to schizophrenia

The majority of genes we chose for validation studies were upregulated in WT mice after ECS compared to Egr3-/- mice following ECS. However, a small number of genes showed increased expression in Egr3-/- mice compared with WT mice after ECS. We chose two genes from this group for validation studies based on their degree of foldchange induction, involvement in behavior and/or DNA damage response, and association with schizophrenia. The first, transcription factor myocyte enhancer factor 2c 
(Mef2c), is a key regulator of learning and memory in vivo ${ }^{55}$. The second, calbindin 2 (Calb2), encodes the protein calretinin, a critical regulator of long-term potentiation in the dentate gyrus ${ }^{56}$. Previous studies showed that enrichment of MEF2C motifs was found in sequences surrounding the top single nucleotide polymorphisms within schizophrenia risk loci ${ }^{57}$ and increased levels of calretinin were reported in the dentate gyrus of schizophrenia and bipolar patients compared to controls ${ }^{58}$.

The Mef2c microarray results showed that ECS caused a decrease in Mef2c expression in WT mice which did not occur in Egr3-/- mice (Fig. 5A, Table 3). The opposing effect of ECS on Mef2c expression resulted in a significant interaction between ECS treatment and genotype in the two-way ANOVA in the microarray, a result that was validated by qRT-PCR in the male mRNAs (Fig. 5A - B, Table 3). In contrast, in females no significant changes in Mef2c expression were seen (Table 3).

Calb2 expression levels showed a pattern that was rare in the dataset. Expression of Calb2 is significantly reduced in Egr3-/- mice compared to WT mice at baseline and does not change in response to ECS in either genotype. This pattern, present in the microarray data and validation qRT-PCR in males (Fig. 5C - D, Table 3), was not significant in the female qRT-PCR results (Table 3 ).

\section{Discussion}

Major advances in genetics and genomics over the last decade and a half have led to identification of hundreds of genes associated with risk for neuropsychiatric and neurodegenerative disorders. One method to identify mechanisms that unite these findings, and thus underlie illness etiology, is to identify the "master regulatory genes" that orchestrate expression of large numbers of these disease-associated genes. EGR3 has been identified as such a master regulator in neuropsychiatric illnesses schizophrenia, bipolar disorder and, most recently, Alzheimer's disease ${ }^{2-4}$. These studies have relied on bioinformatics resources to identify the gene interaction relationships that led to these discoveries. However, few studies have validated the genes that require Egr3 for their expression in the brain in vivo. Our findings reveal numerous genes that are dependent upon Egr3 for their normal expression in response to neuronal activity in the mouse hippocampus. Numerous of these genes either map to schizophrenia GWAS risk loci or have been identified as differentially regulated in schizophrenia studies.

As an immediate early gene transcription factor Egr3 is rapidly expressed in the brain in response to neuronal activity and, in turn, regulates the subsequent set of genes expressed in response to that activity. Egr3 is thus poised to translate environmental stimuli into changes in gene expression that dictate the brain's response to the outside world. Our studies in mice identified the critical roles of Egr3 in stress-responsive behavior, memory, and synaptic plasticity ${ }^{13}, 15$. Based on these findings, and the upstream signaling events that trigger EGR3 expression, we hypothesized that dysfunction of EGR3 would disrupt the brain's resilient response to stress, resulting in neuropathology which, over time, may give rise to symptoms of neuropsychiatric illness $13,15,16$.

Our hypothesis has subsequently been supported by studies showing both genetic association of EGR3 with schizophrenia ${ }^{9,59-61}$, as well as decreased EGR3 gene expression in brains of schizophrenia patients ${ }^{59,62}$ and fibroblasts isolated from 
schizophrenia patients ${ }^{63}$. Recent in silico studies identified EGR3 as a central gene in a network of transcription factors and microRNAs associated with schizophrenia risk ${ }^{2}$, a master regulator of genes that are differentially regulated in bipolar disorder patients ${ }^{3}$, and a critical regulator of DEGs involved in synaptic function in Alzheimer's disease ${ }^{4}$. In total, these findings suggest that altered EGR3 activity, or disruption of proteins that function upstream or downstream of $E G R 3$, may increase risk for neuropsychiatric disorders and play a role of development of neurodegenerative disease.

To identify Egr3-dependent genes in the brain, we used ECS to maximally induce immediate early gene expression in the hippocampi of WT and Egr3-/- mice and identified DEGs using a microarray-based approach. We found genes involved in regulation of behavior and DNA damage response pathways to be significantly overrepresented in our DEG list. Our results suggest that Egr3 is necessary for ECSdependent stimulation of a subset of genes involved in regulation of nervous system function including regulation of memory (Npas $4^{51}, \mathrm{Nr} 4 \mathrm{a}_{2}{ }^{52}$ ), neurogenesis and synaptic plasticity (Gadd45b $\left.{ }^{40}, B_{d n f}{ }^{64}\right)$, behavior $\left(F_{O S}{ }^{65}, F_{o s b}{ }^{66}\right)$ and DNA damage response, particularly, DNA repair (Cenpa ${ }^{43}$, GADD45 family proteins Gadd45b and Gadd45g ${ }^{37,38}$, Fos and Fosb that are part of the AP-1 transcription factor ${ }^{48}$, and $\mathrm{Nr} 4 a 2^{54}$ ). We also report that two genes that show elevated expression in schizophrenia (Calb2 ${ }^{58}$, Mef2c ${ }^{57}$ ) are upregulated in mice lacking Egr3. In total, our findings suggest that Egr3 is critical for the normal activity-responsive expression of genes involved in brain function and the DNA damage response.

\section{The importance of DNA repair in neurons, findings of DNA damage regulating genes involved in behavior}

In neurons, DNA damage can occur during normal cellular activity and in processes involving DNA replication, such as neurogenesis ${ }^{67}$. Neurons are postmitotic, and typically cannot be replaced by new cells if DNA damage reaches critical levels. Therefore, neurons rely heavily on effective DNA repair mechanisms to maintain homeostasis ${ }^{68}$. DNA damage is often associated with aging and disease pathology; however, two recent paradigm-shifting studies highlight the role of DNA damage in regulation of normal physiological function in neurons. The first study, by Suberbeille and colleagues $^{69}$, showed that neuronal activity triggered by exploration of a novel environment can cause DNA damage in the form of DNA double-stranded breaks in the cortex and hippocampus of young adult WT mice. The second study, by Madabhushi and colleagues, demonstrated that in vitro stimulation of primary neurons induced DNA double-stranded breaks in the promoters of immediate early genes that was essential for their activity-dependent induction ${ }^{70}$. They also showed that inhibiting non-homologous end joining, a DNA repair pathway, caused a sustained "switched on" state of gene expression perturbing the normal temporal dynamics of immediate early gene expression.

We found several genes from the Madabhushi study to be differentially expressed in our results. These included Fos, Fosb, Nr4a2 and Npas4, which failed to be induced in Egr3/- mice after ECS, and represented 4 of the 12 genes that showed upregulation in the Madabhushi study following etoposide treatment of neurons ${ }^{70}$. Madabhushi and colleagues also reported that of these genes, Fos, Fosb and Npas 4 showed enrichment of DNA damage double strand breaks $(\mathrm{Y}-\mathrm{H} 2 \mathrm{AX})$ in their promoters and were induced following neuronal activity in vitro ${ }^{70}$. 
We show that Egr3 is necessary for the neuronal activity induced expression of these genes. Given the roles of these genes in regulation of neuronal function, impaired expression of these genes may contribute to the behavioral and cognitive deficits seen in Egr3-/- mice ${ }^{13,71}$. In addition to playing a role in behavior regulation, Fos and Fosb are members of the AP-1 transcription factor complex, a critical regulator of DNA repair genes ${ }^{48}$. In line with these data, we also found that genes belonging to the GADD45 signaling pathway, a major DNA damage response pathway ${ }^{37,38}$, showed impaired induction in Egr3-/- mice following ECS. GADD45b was recently identified as an EGR3 dependent gene in prostate cancer, and EGR3 was shown to bind to the GADD45B promoter in vivo and upregulate expression of GADD45B in vitro ${ }^{72}$.

In addition, other DNA damage response genes including Cenpa and Nr4a2, recently shown to play a role in DNA repair ${ }^{43,54}$ showed a similar lack of induction in the Egr3-/mice after undergoing ECS. For several of these genes we saw particularly robust induction following ECS in wildtype mice including a 12-fold induction for Cenpa and a 15-fold induction for Fos that the Egr3-/- mice lacked. Given that EGR3 is induced in response to DNA damaging stimuli in vitro ${ }^{73}$, our findings suggest that lack of functional Egr3 results in diminished activation of genes involved in DNA damage response. This dysfunction of Egr3 may increase susceptibility to DNA damage, impacting normal physiological activation of genes and contributing to increased DNA damage observed in neuropsychiatric illness ${ }^{74-78}$.

\section{Genes upregulated in Egr3-/- mice}

While the majority of DEGs in our data failed to be induced by ECS in Egr3-/- mice, a small subset showed the opposite trend. Key among these genes were Mef2c and Calb2, which showed the most profound increase in Egr3-/- mice following ECS compared to WT mice. Prior studies show that both of these genes show increased expression in schizophrenia patients' brains ${ }^{57,58}$. A previous study showed that deletion of Mef2c impairs hippocampal-dependent learning and memory in vivo ${ }^{55}$. Also, Mef2c limits excessive synapse formation during activity-dependent synaptogenesis in the dentate gyrus ${ }^{55}$. Mice lacking the Calb2 encoded protein calretinin, show impaired hippocampal long-term potentiation (LTP) ${ }^{79}$. Studies suggest that temporal and spatial regulation of MEF2 family members ${ }^{80}$ and Calb2 ${ }^{81}$ is essential for normal brain development.

Both timing and level of immediate early gene expression are critical features of their function. Either insufficient expression, or persistent overexpression, of immediate early genes, or the factors that regulate them, can negatively affect learning ${ }^{82}$, or cause anxiety-like behavior, respectively ${ }^{83}$. Our findings indicate that Egr3 may influence the temporal regulation of these genes, where a lack of Egr3 may lead to a perpetual "switched on" state of gene expression for genes such as Mef2c and Calb2 that is not observed in WT mice, and may negatively impact normal brain function.

In summary, we report activity-dependent gene expression changes in the hippocampus of Egr3-/- mice, previously shown to exhibit schizophrenia-like behavioral abnormalities and memory deficits ${ }^{13,15}$. We have validated numerous genes that were differentially expressed in the microarray data using qRT-PCR in the original male RNAs and a replication cohort of female mice, demonstrating that many of these effects are independent of sex while others appear sex-dependent. These genes are involved in behavior and DNA damage response, with a subset of these playing dual roles in 
neuronal function and DNA repair including Gadd45b, Nr4a2 and Bdnf. Further studies are needed to define the role of EGR3 in regulating DNA response genes necessary to repair DNA double strand breaks induced by neuronal activity. In conclusion, our studies demonstrate that EGR3 is a critical dual regulator of behavior and DNA damage response genes, and further define its role in brain function and neuropsychiatric and neurodegenerative illnesses characterized by cognitive dysfunction. The identification of EGR3-dependent genes in the mouse hippocampus may help to explain finding indicating that EGR3 may be a master regulator of genes differentially expressed in neuropsychiatric illnesses ranging from schizophrenia and bipolar disorder to Alzheimer's disease ${ }^{2-4}$.

\section{Acknowledgements}

The authors gratefully acknowledge the assistance of past and present members of the Gallitano Lab Aneri Mehta, Annika Ozols, and Xiuli Zhao, PhD. Research reported in this publication was supported by the National Institute of Mental Health of the National Institutes of Health (NIH) under Award Numbers R01MH097803 and R21MH113154 (to ALG), and R01MH107487 and R01MH121102 (to RRM), and by the National Institute on Aging of NIH under Award Number R01AG057598 (to RRM). The content is solely the responsibility of the authors and does not necessarily represent the official views of the $\mathrm{NIH}$.

\section{Conflict of Interest}

The authors have no competing financial interests in relation to the work described in this manuscript.

\section{Figure Legends}

Figure 1. EGR3-dependent genes show altered expression in schizophrenia studies. A. Expression heatmap of genes differentially expressed in WT versus Egr3-/mice following ECS. Expression microarray revealed 71 genes that were differentially expressed in the hippocampus of Egr3-/- mice compared to WT one hour following ECS. The average expression level for each of these genes is shown along a horizontal row in WT (left) and Egr3-/- mice (right) at baseline, and $1 \mathrm{hr}$ and $2 \mathrm{hrs}$ following ECS. ( $\mathrm{n}=4$ animals per condition). B. Fourteen published gene expression studies in schizophrenia were queried for the 71 genes that are differentially expressed in Egr3-/- compared with WT mouse hippocampus $1 \mathrm{hr}$ following ECS. The heatmap shows normalized log 2 fold change values (schizophrenia vs. control) from the 14 published study datasets (vertical columns) for each of the 71 EGR3-dependent genes (horizontal rows).

Figure 2. Top canonical pathways and physiological function categories associated with DEGs generated by IPA. Ingenuity Pathway "core analysis" performed on microarray results reveals pathways associated with the genes that are differentially expressed in hippocampus from Egr3-/- vs. WT mice following ECS. A. "Threshold" indicates the minimum significance level [scored as -log ( $p$-value) from Fisher's exact test, set here to $p<0.05]$. "Ratio" (yellow points) indicate the number of molecules from the DEG dataset that map to the pathway listed, divided by the total number of molecules that map to the canonical pathway from the IPA knowledgebase. B. DEGs are most significantly enriched for genes involved in regulation of behavior. The top 5 scoring pathways in Physiological System Development and Function are shown with 
significance ranges for subcategories within each hit ( $p$-value range) and number of molecules associated.

Figure 3. GADD45 family genes are differentially expressed in Egr3-/- mice. A. GADD45B pathway figure generated by IPA showing signaling components involved. Pink outline indicates molecules that are differentially expressed in Egr3-/-, compared with WT, mice following ECS. These include GADD45B and GADD45G. B. - C. Expression microarray results of GADD45B pathway gene expression in hippocampus from WT and Egr3-/- mice at baseline (No ECS) and 1 hour after ECS. B. Gadd45b, C. Gadd45g. D. - E. Quantitative RT-PCR validation of Gadd45b in D. The original male cohort and E. the replication female cohort. F. qRT-PCR validation of Gadd $45 \mathrm{~g}$ results in original male cohort. ( $n=4-5$ animals/group; ${ }^{*} p<0.05,{ }^{* *} p<0.01,{ }^{* * *} p<0.001$, controlled for multiple comparisons). Statistical analyses for these, and all subsequent graphs, are shown in Table 3.

Figure 4. Numerous genes are differentially expressed in Egr3-/- mice compared with WT mice following ECS. Microarray analysis results (i) and follow-up qRT-PCR results performed in the original RNA samples used in the microarray (ii) and in a replication cohort of female mice (iii) for $\mathrm{A}$. Cenpa, the most highly differentially expressed gene in the dataset, AP-1 family genes B. Fos and C. Fosb, and additional memory-related genes D. Npas4 and E. Nr4a2, which is also involved in DNA repair. (n $=4-5$ animals/group; ${ }^{*} p<0.05,{ }^{* *} p<0.01,{ }^{* * *} p<0.001,{ }^{* * * *} p<0.0001$, controlled for multiple comparisons).

Figure 5. Mef2c and Calb2 display unique patterns of regulation. Microarray analysis results ( $A$ and $C$ ) and follow-up qRT-PCR results in males (B and $D)$ for schizophrenia associated gene Mef2c (A-B) and Calb2 (C-D), genes overexpressed in schizophrenia. ( $n=4$ animals/group; ${ }^{* *} p<0.01,{ }^{* * *} p<0.001$, controlled for multiple comparisons). 


\section{$\underline{\text { References }}$}

1. Brainstorm C, Anttila V, Bulik-Sullivan B, Finucane HK, Walters RK, Bras J et al. Analysis of shared heritability in common disorders of the brain. Science 2018; 360(6395).

2. Guo AY, Sun J, Jia P, Zhao Z. A novel microRNA and transcription factor mediated regulatory network in schizophrenia. BMC systems biology 2010; 4: 10.

3. Pfaffenseller B, da Silva Magalhaes PV, De Bastiani MA, Castro MA, Gallitano AL, Kapczinski F et al. Differential expression of transcriptional regulatory units in the prefrontal cortex of patients with bipolar disorder: potential role of early growth response gene 3. Transl Psychiatry 2016; 6: e805.

4. Canchi S, Raao B, Masliah D, Rosenthal SB, Sasik R, Fisch KM et al. Integrating Gene and Protein Expression Reveals Perturbed Functional Networks in Alzheimer's Disease. Cell Rep 2019; 28(4): 1103-1116 e1104.

5. Li L, Carter J, Gao X, Whitehead J, Tourtellotte WG. The neuroplasticityassociated arc gene is a direct transcriptional target of early growth response (Egr) transcription factors. Molecular and cellular biology 2005; 25(23): 10286-10300.

6. Kirov G, Pocklington AJ, Holmans P, Ivanov D, Ikeda M, Ruderfer D et al. De novo CNV analysis implicates specific abnormalities of postsynaptic signalling complexes in the pathogenesis of schizophrenia. Molecular psychiatry 2012; 17(2): 142-153.

7. Fromer M, Pocklington AJ, Kavanagh DH, Williams HJ, Dwyer S, Gormley P et al. De novo mutations in schizophrenia implicate synaptic networks. Nature 2014; 506(7487): 179-184.

8. Purcell SM, Moran JL, Fromer M, Ruderfer D, Solovieff N, Roussos P et al. A polygenic burden of rare disruptive mutations in schizophrenia. Nature 2014; 506(7487): 185-190.

9. Huentelman MJ, Muppana L, Corneveaux JJ, Dinu V, Pruzin JJ, Reiman R et al. Association of SNPs in EGR3 and ARC with Schizophrenia Supports a Biological Pathway for Schizophrenia Risk. PloS one 2015; 10(10): e0135076.

10. Roberts DS, Hu Y, Lund IV, Brooks-Kayal AR, Russek SJ. Brain-derived neurotrophic factor (BDNF)-induced synthesis of early growth response factor 3 (Egr3) controls the levels of type A GABA receptor alpha 4 subunits in hippocampal neurons. J Biol Chem 2006; 281(40): 29431-29435. 
11. Roberts DS, Raol YH, Bandyopadhyay S, Lund IV, Budreck EC, Passini MA et al. Egr3 stimulation of GABRA4 promoter activity as a mechanism for seizure-induced up-regulation of GABA(A) receptor alpha4 subunit expression. Proceedings of the National Academy of Sciences of the United States of America 2005; 102(33): 11894-11899.

12. Riley JD, Delahunty C, Alsadah A, Mazzola S, Astbury C. Further evidence of GABRA4 and TOP3B as autism susceptibility genes. Eur J Med Genet 2020; 63(5): 103876.

13. Gallitano-Mendel A, Izumi Y, Tokuda K, Zorumski CF, Howell MP, Muglia LJ et al. The immediate early gene early growth response gene 3 mediates adaptation to stress and novelty. Neuroscience 2007; 148(3): 633-643.

14. Olney JW, Newcomer JW, Farber NB. NMDA receptor hypofunction model of schizophrenia. Journal of psychiatric research 1999; 33(6): 523-533.

15. Gallitano-Mendel A, Wozniak DF, Pehek EA, Milbrandt J. Mice lacking the immediate early gene Egr3 respond to the anti-aggressive effects of clozapine yet are relatively resistant to its sedating effects. Neuropsychopharmacology: official publication of the American College of Neuropsychopharmacology 2008; 33(6): 1266-1275.

16. Marballi KK, Gallitano AL. Immediate Early Genes Anchor a Biological Pathway of Proteins Required for Memory Formation, Long-Term Depression and Risk for Schizophrenia. Frontiers in behavioral neuroscience 2018; 12: 23.

17. Yamagata K, Kaufmann WE, Lanahan A, Papapavlou M, Barnes CA, Andreasson KI et al. Egr3/Pilot, a zinc finger transcription factor, is rapidly regulated by activity in brain neurons and colocalizes with Egr1/zif268. Learning \& memory 1994; 1(2): 140-152.

18. Kumbrink J, Kirsch KH, Johnson JP. EGR1, EGR2, and EGR3 activate the expression of their coregulator NAB2 establishing a negative feedback loop in cells of neuroectodermal and epithelial origin. Journal of cellular biochemistry 2010; 111(1): 207-217.

19. Pardinas AF, Holmans P, Pocklington AJ, Escott-Price V, Ripke S, Carrera N et al. Common schizophrenia alleles are enriched in mutation-intolerant genes and in regions under strong background selection. Nature genetics 2018; 50(3): 381-389.

20. Schizophrenia Working Group of the Psychiatric Genomics C. Biological insights from 108 schizophrenia-associated genetic loci. Nature 2014; 511(7510): 421-427. 
21. Liu D, Evans I, Britton G, Zachary I. The zinc-finger transcription factor, early growth response 3, mediates VEGF-induced angiogenesis. Oncogene 2008; 27(21): 2989-2998.

22. Jones MW, Errington ML, French PJ, Fine A, Bliss TV, Garel S et al. A requirement for the immediate early gene Zif268 in the expression of late LTP and long-term memories. Nature neuroscience 2001; 4(3): 289-296.

23. Nagarajan R, Svaren J, Le N, Araki T, Watson M, Milbrandt J. EGR2 mutations in inherited neuropathies dominant-negatively inhibit myelin gene expression. Neuron 2001; 30(2): 355-368.

24. Meyers KT, Marballi KK, Brunwasser SJ, Renda B, Charbel M, Marrone DF et al. The Immediate Early Gene Egr3 Is Required for Hippocampal Induction of Bdnf by Electroconvulsive Stimulation. Frontiers in behavioral neuroscience 2018; 12: 92.

25. Hastings KT, Elizalde D, Muppana L, Levine S, Kamel CM, Ingram WM et al. Nab2 maintains thymus cellularity with aging and stress. Mol Immunol 2017; 85: 185-195.

26. Suehiro J, Hamakubo T, Kodama T, Aird WC, Minami T. Vascular endothelial growth factor activation of endothelial cells is mediated by early growth response-3. Blood 2010; 115(12): 2520-2532.

27. Li S, Miao T, Sebastian M, Bhullar P, Ghaffari E, Liu M et al. The transcription factors Egr2 and Egr3 are essential for the control of inflammation and antigen-induced proliferation of B and T cells. Immunity 2012; 37(4): 685696.

28. Weigelt K, Carvalho LA, Drexhage RC, Wijkhuijs A, de Wit H, van Beveren NJ et al. TREM-1 and DAP12 expression in monocytes of patients with severe psychiatric disorders. EGR3, ATF3 and PU.1 as important transcription factors. Brain, behavior, and immunity 2011; 25(6): 1162-1169.

29. Tourtellotte WG, Milbrandt J. Sensory ataxia and muscle spindle agenesis in mice lacking the transcription factor Egr3. Nature genetics 1998; 20(1): 8791.

30. Wescombe L, Lahooti H, Gopinath B, Wall JR. The cardiac calsequestrin gene (CASQ2) is up-regulated in the thyroid in patients with Graves' ophthalmopathy--support for a role of autoimmunity against calsequestrin as the triggering event. Clin Endocrinol (Oxf) 2010; 73(4): 522-528. 
31. Fan X, Shi L, Fang H, Harris S, Perkins R, Tong W. Investigation of reproducibility of differentially expressed genes in DNA microarrays through statistical simulation. BMC Proc 2009; 3 Suppl 2: S4.

32. Maple AM, Zhao X, Elizalde DI, McBride AK, Gallitano AL. Htr2a Expression Responds Rapidly to Environmental Stimuli in an Egr3-Dependent Manner. ACS Chem Neurosci 2015; 6(7): 1137-1142.

33. Le H, Zeng F, Xu L, Liu X, Huang Y. The role of CD133 expression in the carcinogenesis and prognosis of patients with lung cancer. Mol Med Rep 2013; 8(5): 1511-1518.

34. Jin S, Mazzacurati L, Zhu X, Tong T, Song Y, Shujuan S et al. Gadd45a contributes to p53 stabilization in response to DNA damage. Oncogene 2003; 22(52): 8536-8540.

35. Blackford AN, Jackson SP. ATM, ATR, and DNA-PK: The Trinity at the Heart of the DNA Damage Response. Mol Cell 2017; 66(6): 801-817.

36. Barry SP, Townsend PA, Knight RA, Scarabelli TM, Latchman DS, Stephanou A. STAT3 modulates the DNA damage response pathway. Int J Exp Pathol 2010; 91(6): 506-514.

37. Smith ML, Ford JM, Hollander MC, Bortnick RA, Amundson SA, Seo YR et al. p53-mediated DNA repair responses to UV radiation: studies of mouse cells lacking p53, p21, and/or gadd45 genes. Mol Cell Biol 2000; 20(10): 37053714.

38. Smith ML, Chen IT, Zhan Q, Bae I, Chen CY, Gilmer TM et al. Interaction of the p53-regulated protein Gadd45 with proliferating cell nuclear antigen. Science 1994; 266(5189): 1376-1380.

39. Barreto G, Schafer A, Marhold J, Stach D, Swaminathan SK, Handa V et al. Gadd45a promotes epigenetic gene activation by repair-mediated DNA demethylation. Nature 2007; 445(7128): 671-675.

40. Ma DK, Jang MH, Guo JU, Kitabatake Y, Chang ML, Pow-Anpongkul N et al. Neuronal activity-induced Gadd45b promotes epigenetic DNA demethylation and adult neurogenesis. Science 2009; 323(5917): 1074-1077.

41. Takekawa M, Saito H. A family of stress-inducible GADD45-like proteins mediate activation of the stress-responsive MTK1/MEKK4 MAPKKK. Cell 1998; 95(4): 521-530. 
42. Hoffmann S, Dumont M, Barra V, Ly P, Nechemia-Arbely Y, McMahon MA et al. CENP-A Is Dispensable for Mitotic Centromere Function after Initial Centromere/Kinetochore Assembly. Cell Rep 2016; 17(9): 2394-2404.

43. Lawrence KS, Chau T, Engebrecht J. DNA damage response and spindle assembly checkpoint function throughout the cell cycle to ensure genomic integrity. PLoS Genet 2015; 11(4): e1005150.

44. Eferl R, Wagner EF. AP-1: a double-edged sword in tumorigenesis. Nat Rev Cancer 2003; 3(11): 859-868.

45. Angel P, Hattori K, Smeal T, Karin M. The jun proto-oncogene is positively autoregulated by its product, Jun/AP-1. Cell 1988; 55(5): 875-885.

46. Foletta VC, Segal DH, Cohen DR. Transcriptional regulation in the immune system: all roads lead to AP-1. J Leukoc Biol 1998; 63(2): 139-152.

47. Mruthyunjaya S, Rumma M, Ravibhushan G, Anjali S, Padma S. c-Jun/AP-1 transcription factor regulates laminin-1-induced neurite outgrowth in human bone marrow mesenchymal stem cells: role of multiple signaling pathways. FEBS Lett 2011; 585(12): 1915-1922.

48. Christmann M, Tomicic MT, Aasland D, Berdelle N, Kaina B. Three prime exonuclease I (TREX1) is Fos/AP-1 regulated by genotoxic stress and protects against ultraviolet light and benzo(a)pyrene-induced DNA damage. Nucleic Acids Res 2010; 38(19): 6418-6432.

49. Bloodgood BL, Sharma N, Browne HA, Trepman AZ, Greenberg ME. The activity-dependent transcription factor NPAS4 regulates domain-specific inhibition. Nature 2013; 503(7474): 121-125.

50. Lin Y, Bloodgood BL, Hauser JL, Lapan AD, Koon AC, Kim TK et al. Activitydependent regulation of inhibitory synapse development by Npas4. Nature 2008; 455(7217): 1198-1204.

51. Shepard R, Heslin K, Coutellier L. The transcription factor Npas4 contributes to adolescent development of prefrontal inhibitory circuits, and to cognitive and emotional functions: Implications for neuropsychiatric disorders. Neurobiol Dis 2017; 99: 36-46.

52. McNulty SE, Barrett RM, Vogel-Ciernia A, Malvaez M, Hernandez N, Davatolhagh MF et al. Differential roles for Nr4a1 and Nr4a2 in object location vs. object recognition long-term memory. Learn Mem 2012; 19(12): 588-592. 
53. Kim JI, Jeon SG, Kim KA, Kim YJ, Song EJ, Choi J et al. The pharmacological stimulation of Nurr1 improves cognitive functions via enhancement of adult hippocampal neurogenesis. Stem Cell Res 2016; 17(3): 534-543.

54. Yin K, Chhabra Y, Tropee R, Lim YC, Fane M, Dray E et al. NR4A2 Promotes DNA Double-strand Break Repair Upon Exposure to UVR. Mol Cancer Res 2017; 15(9): 1184-1196.

55. Barbosa AC, Kim MS, Ertunc M, Adachi M, Nelson ED, McAnally J et al. MEF2C, a transcription factor that facilitates learning and memory by negative regulation of synapse numbers and function. Proc Natl Acad Sci U S A 2008; 105(27): 9391-9396.

56. Gurden H, Schiffmann SN, Lemaire M, Bohme GA, Parmentier M, Schurmans S. Calretinin expression as a critical component in the control of dentate gyrus long-term potentiation induction in mice. Eur J Neurosci 1998; 10(9): 3029-3033.

57. Mitchell AC, Javidfar B, Pothula V, Ibi D, Shen EY, Peter CJ et al. MEF2C transcription factor is associated with the genetic and epigenetic risk architecture of schizophrenia and improves cognition in mice. Mol Psychiatry 2018; 23(1): 123-132.

58. Walton NM, Zhou Y, Kogan JH, Shin R, Webster M, Gross AK et al. Detection of an immature dentate gyrus feature in human schizophrenia/bipolar patients. Transl Psychiatry 2012; 2: e135.

59. Yamada K, Gerber DJ, Iwayama Y, Ohnishi T, Ohba H, Toyota T et al. Genetic analysis of the calcineurin pathway identifies members of the EGR gene family, specifically EGR3, as potential susceptibility candidates in schizophrenia. Proceedings of the National Academy of Sciences of the United States of America 2007; 104(8): 2815-2820.

60. Kim SH, Song JY, Joo EJ, Lee KY, Ahn YM, Kim YS. EGR3 as a potential susceptibility gene for schizophrenia in Korea. American journal of medical genetics Part B, Neuropsychiatric genetics : the official publication of the International Society of Psychiatric Genetics 2010; 153B(7): 1355-1360.

61. Zhang R, Lu S, Meng L, Min Z, Tian J, Valenzuela RK et al. Genetic evidence for the association between the early growth response 3 (EGR3) gene and schizophrenia. PloS one 2012; 7(1): e30237.

62. Mexal S, Frank M, Berger R, Adams CE, Ross RG, Freedman R et al. Differential modulation of gene expression in the NMDA postsynaptic density of schizophrenic and control smokers. Brain research Molecular brain research 2005; 139(2): 317-332. 
63. Etemadikhah M, Niazi A, Wetterberg L, Feuk L. Transcriptome analysis of fibroblasts from schizophrenia patients reveals differential expression of schizophrenia-related genes. Sci Rep 2020; 10(1): 630.

64. Leal G, Bramham CR, Duarte CB. BDNF and Hippocampal Synaptic Plasticity. Vitam Horm 2017; 104: 153-195.

65. Brown JR, Ye H, Bronson RT, Dikkes P, Greenberg ME. A defect in nurturing in mice lacking the immediate early gene fosB. Cell 1996; 86(2): 297-309.

66. Hiroi N, Brown JR, Haile CN, Ye H, Greenberg ME, Nestler EJ. FosB mutant mice: loss of chronic cocaine induction of Fos-related proteins and heightened sensitivity to cocaine's psychomotor and rewarding effects. Proc Natl Acad Sci U S A 1997; 94(19): 10397-10402.

67. McKinnon PJ. DNA repair deficiency and neurological disease. Nat Rev Neurosci 2009; 10(2): 100-112.

68. McKinnon PJ. Maintaining genome stability in the nervous system. Nature neuroscience 2013; 16(11): 1523-1529.

69. Suberbielle E, Sanchez PE, Kravitz AV, Wang X, Ho K, Eilertson K et al. Physiologic brain activity causes DNA double-strand breaks in neurons, with exacerbation by amyloid-beta. Nature neuroscience 2013; 16(5): 613-621.

70. Madabhushi R, Gao F, Pfenning AR, Pan L, Yamakawa S, Seo J et al. ActivityInduced DNA Breaks Govern the Expression of Neuronal Early-Response Genes. Cell 2015; 161(7): 1592-1605.

71. Li L, Yun SH, Keblesh J, Trommer BL, Xiong H, Radulovic J et al. Egr3, a synaptic activity regulated transcription factor that is essential for learning and memory. Molecular and cellular neurosciences 2007; 35(1): 76-88.

72. Shin SH, Kim I, Lee JE, Lee M, Park JW. Loss of EGR3 is an independent risk factor for metastatic progression in prostate cancer. Oncogene 2020; 39(36): 5839-5854.

73. Andley UP, Patel HC, Xi JH, Bai F. Identification of genes responsive to UV-A radiation in human lens epithelial cells using complementary DNA microarrays. Photochem Photobiol 2004; 80: 61-71.

74. Catts VS, Catts SV, Jablensky A, Chandler D, Weickert CS, Lavin MF. Evidence of aberrant DNA damage response signalling but normal rates of DNA repair in dividing lymphoblasts from patients with schizophrenia. World J Biol Psychiatry 2012; 13(2): 114-125. 
75. Madabhushi R, Pan L, Tsai LH. DNA damage and its links to neurodegeneration. Neuron 2014; 83(2): 266-282.

76. Wang M, Wei PC, Lim CK, Gallina IS, Marshall S, Marchetto MC et al. Increased Neural Progenitor Proliferation in a hiPSC Model of Autism Induces Replication Stress-Associated Genome Instability. Cell Stem Cell 2020; 26(2): 221-233 e226.

77. Markkanen E, Meyer U, Dianov GL. DNA Damage and Repair in Schizophrenia and Autism: Implications for Cancer Comorbidity and Beyond. Int J Mol Sci 2016; 17(6).

78. Ceylan D, Yilmaz S, Tuna G, Kant M, Er A, Ildiz A et al. Alterations in levels of 8-0xo-2'-deoxyguanosine and 8-Oxoguanine DNA glycosylase 1 during a current episode and after remission in unipolar and bipolar depression. Psychoneuroendocrinology 2020; 114: 104600.

79. Schurmans S, Schiffmann SN, Gurden H, Lemaire M, Lipp HP, Schwam V et al. Impaired long-term potentiation induction in dentate gyrus of calretinindeficient mice. Proceedings of the National Academy of Sciences of the United States of America 1997; 94(19): 10415-10420.

80. Lyons GE, Micales BK, Schwarz J, Martin JF, Olson EN. Expression of mef2 genes in the mouse central nervous system suggests a role in neuronal maturation. The Journal of neuroscience : the official journal of the Society for Neuroscience 1995; 15(8): 5727-5738.

81. Al-Jaberi N, Lindsay S, Sarma S, Bayatti N, Clowry GJ. The early fetal development of human neocortical GABAergic interneurons. Cereb Cortex 2015; 25(3): 631-645.

82. Eagle AL, Gajewski PA, Yang M, Kechner ME, Al Masraf BS, Kennedy PJ et al. Experience-Dependent Induction of Hippocampal DeltaFosB Controls Learning. J Neurosci 2015; 35(40): 13773-13783.

83. Kwon W, Kim HS, Jeong J, Sung Y, Choi M, Park S et al. Tet1 overexpression leads to anxiety-like behavior and enhanced fear memories via the activation of calcium-dependent cascade through Egr1 expression in mice. FASEB J 2018; 32(1): 390-403. 
bioRxiv preprint doi: https://doi.org/10.1101/2020.09.01.276626; this version posted April 21, 2021. The copyright holder for this preprint (which was not certified by peer review) is the author/funder. All rights reserved. No reuse allowed without permission.

\section{Figure 1}

A.

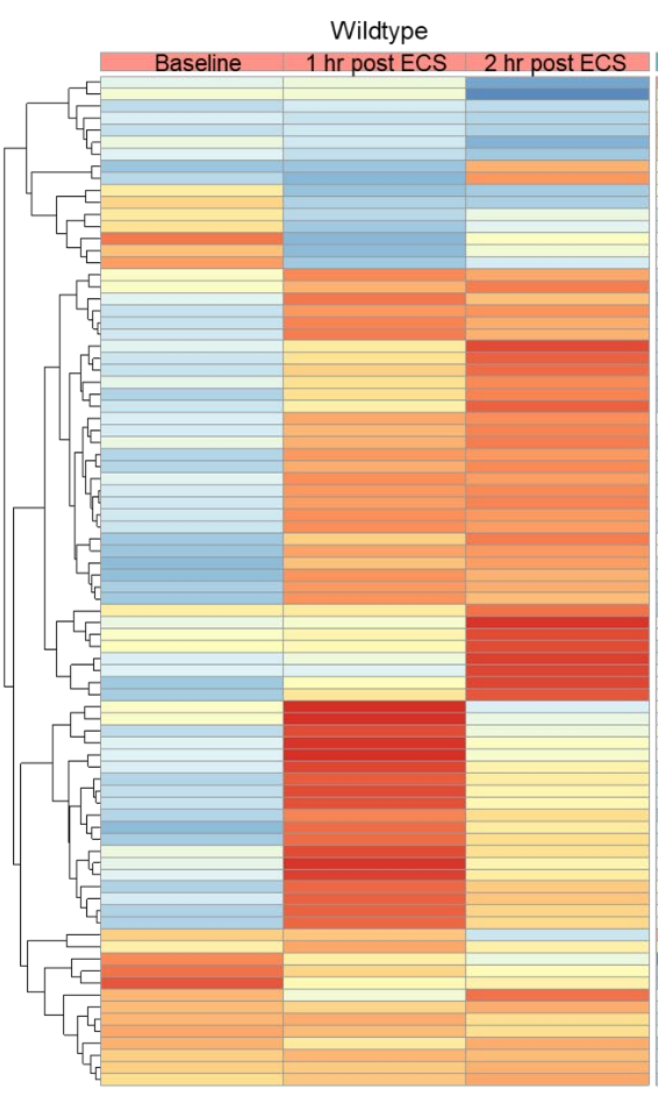

Egr3-/-

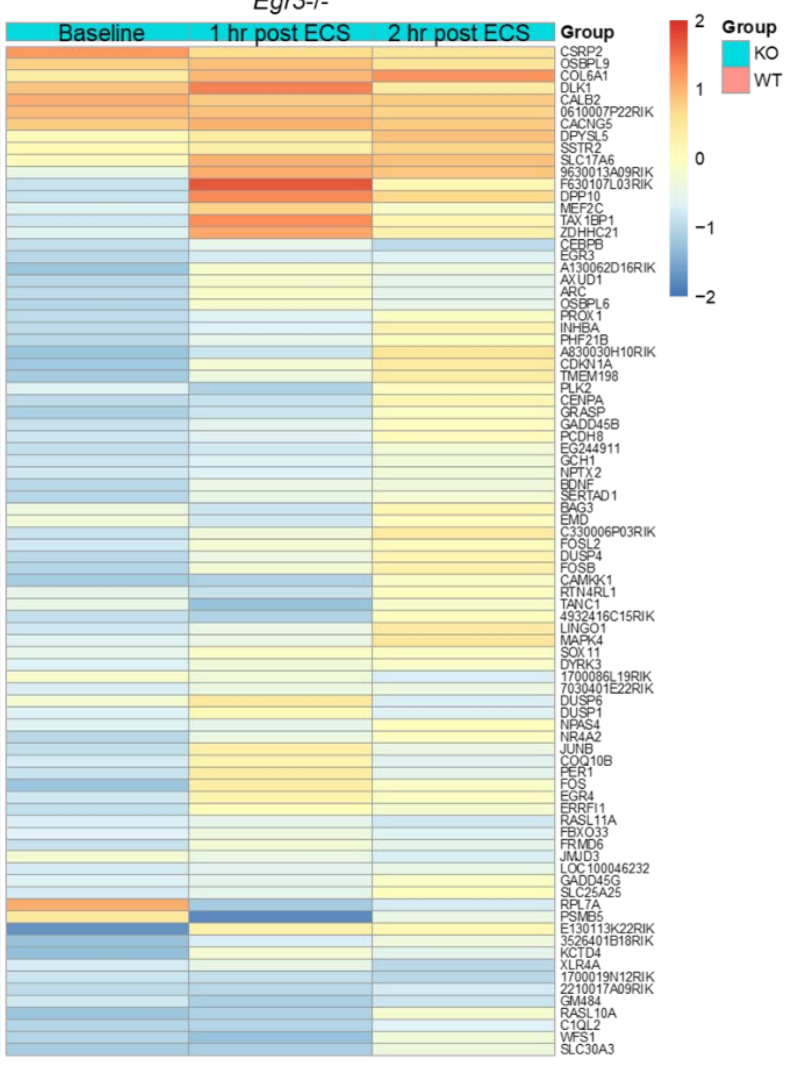

B.

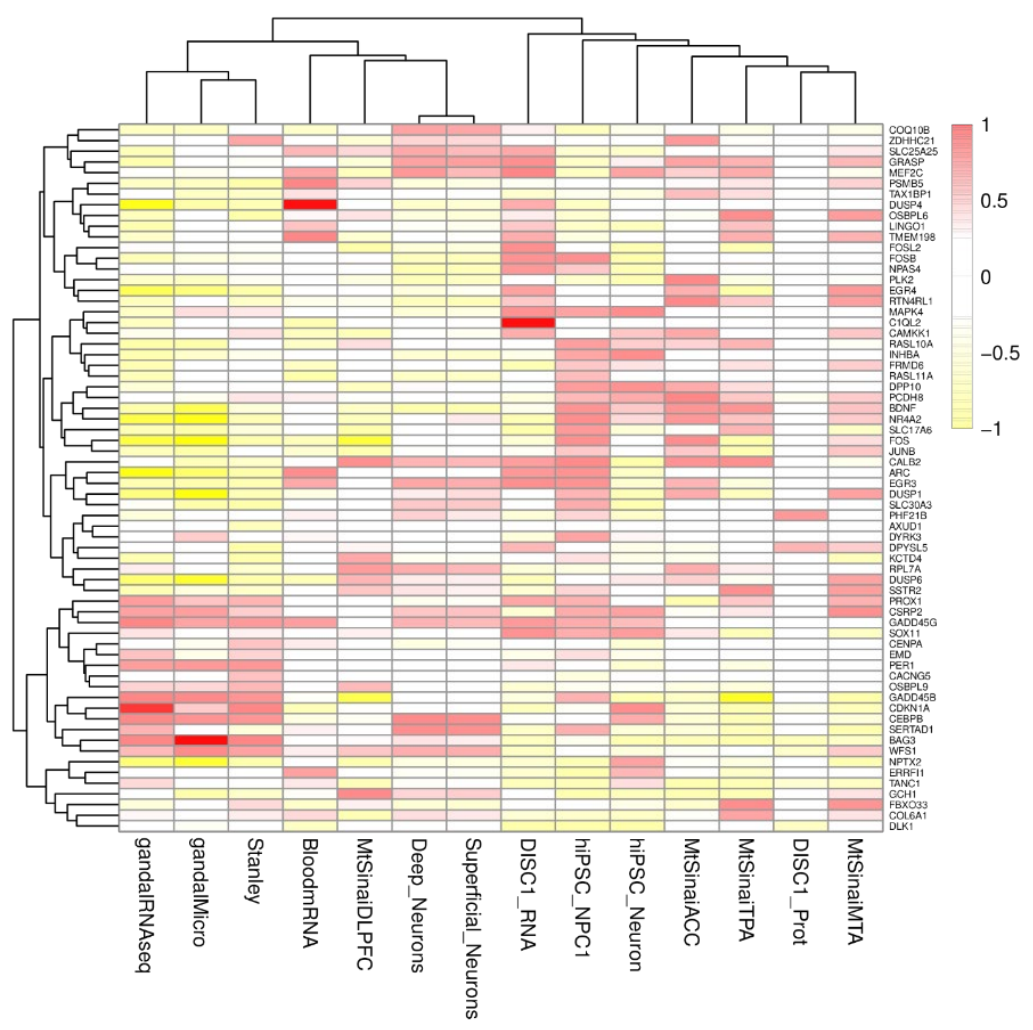


Figure 2.

A.

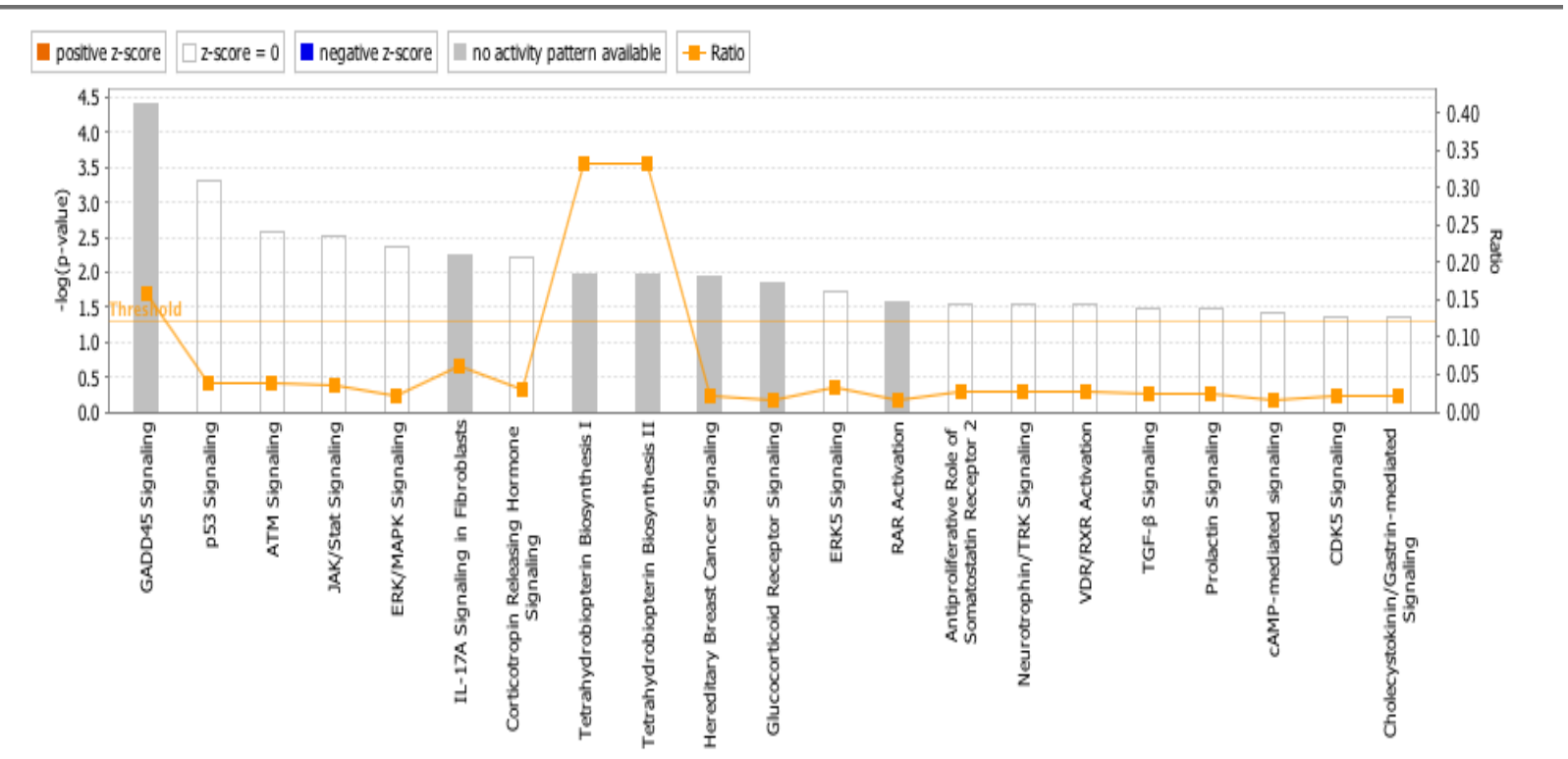

B.

\section{$\checkmark$ Physiological System Development and Function}

\begin{tabular}{|c|c|c|c|}
\hline Name & \multicolumn{2}{|c|}{$p$-value range } & \# Molecules \\
\hline Behavior & ma? & $3.53 \mathrm{E}-03-1.17 \mathrm{E}-11$ & 26 \\
\hline Tissue Morphology & оp.... & $3.65 \mathrm{E}-03-8.10 \mathrm{E}-09$ & 32 \\
\hline Connective Tissue Development and Function & $4 q^{2} \cdot 3$ & $3.53 \mathrm{E}-03-3.24 \mathrm{E}-08$ & 28 \\
\hline Tissue Development & 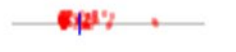 & $3.76 \mathrm{E}-03-3.24 \mathrm{E}-08$ & 35 \\
\hline Reproductive System Development and Function & 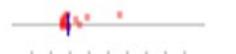 & $3.53 \mathrm{E}-03-3.45 \mathrm{E}-06$ & 12 \\
\hline
\end{tabular}


Figure 3.

A.

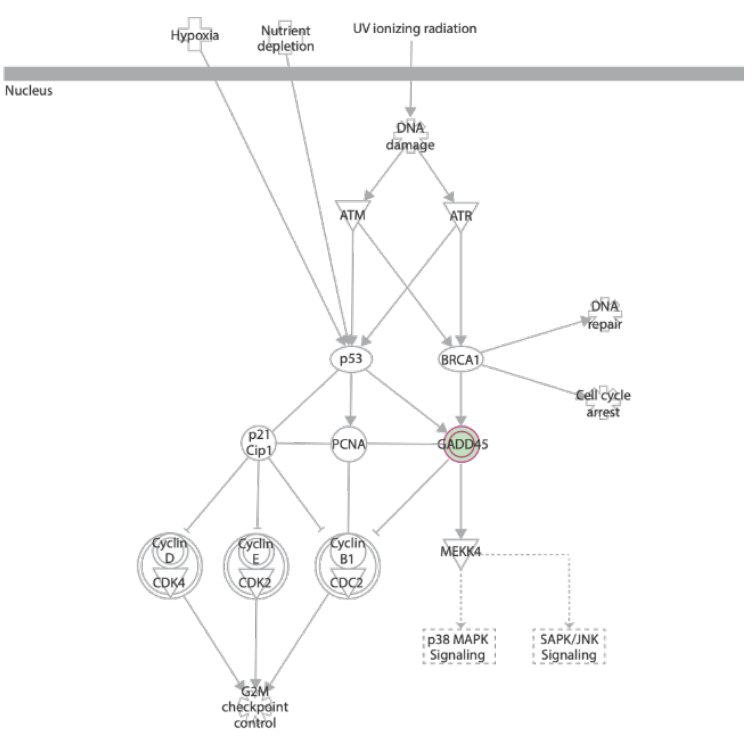

C. Microarray Gadd45g expression

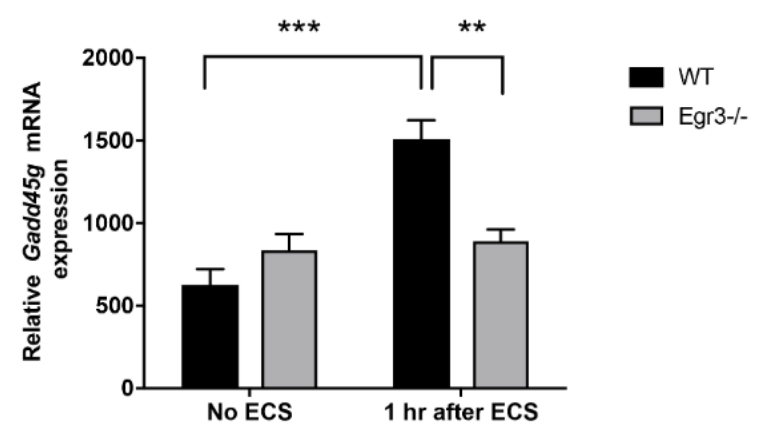

\section{E. Female qRT-PCR Gadd45b expression}

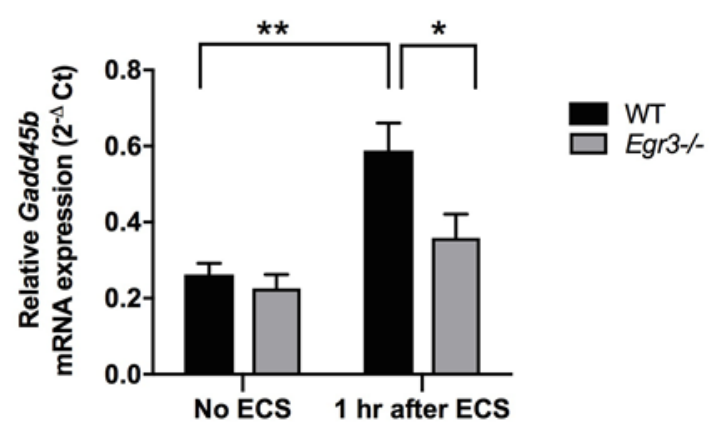

\section{B. Microarray Gadd45b expression}

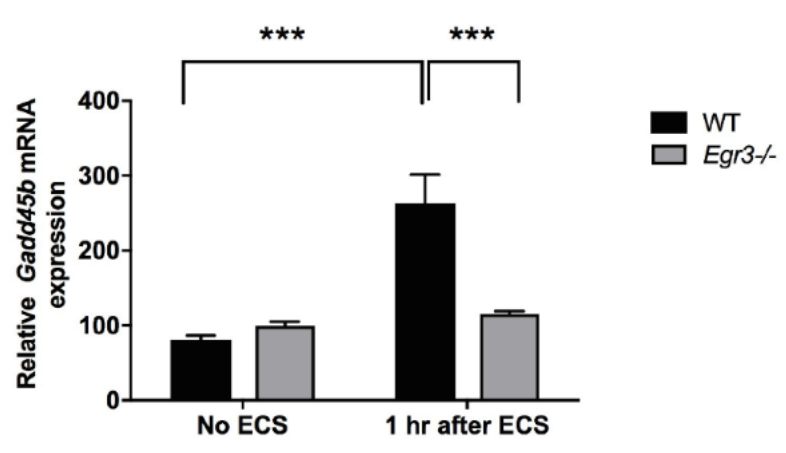

D. Male qRT-PCR Gadd45b expression

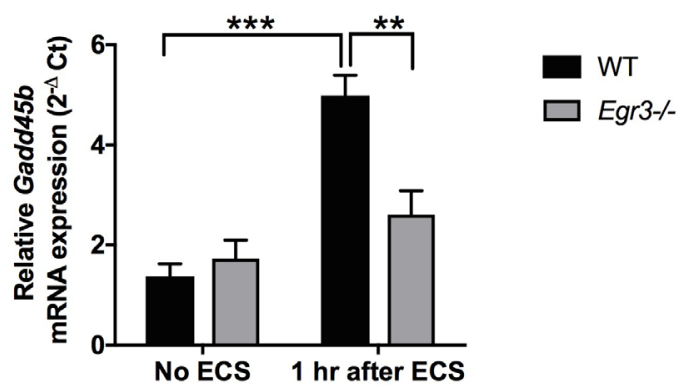

F. Male qRT-PCR Gadd45g expression

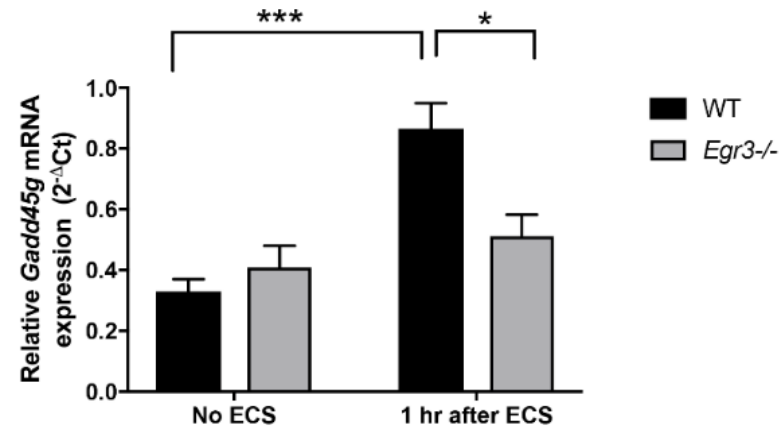


Figure 4.

\section{Microarray}

Ai

Male microarray Cenpa expression

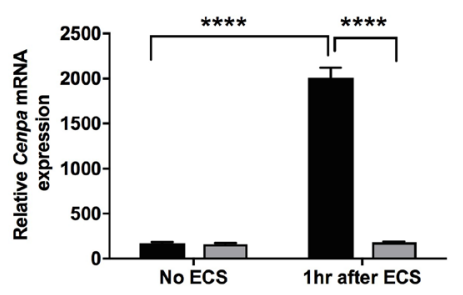

Bi Male microarray Fos expression

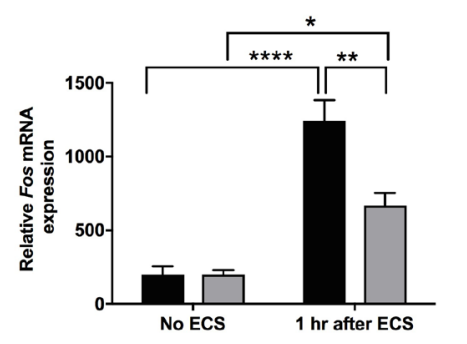

Ci Male microarray Fosb expression

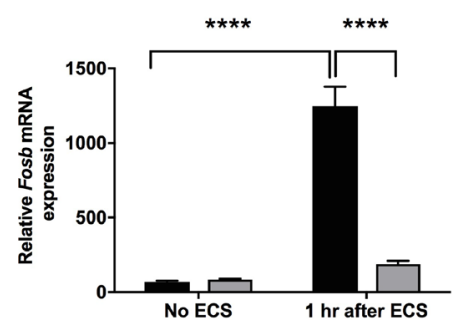

qRT-PCR Original mRNAs

Aii

Male qRT PCR Cenpa expression

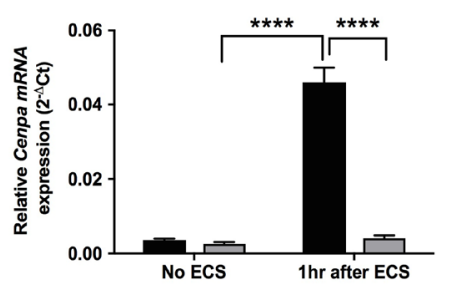

Bii

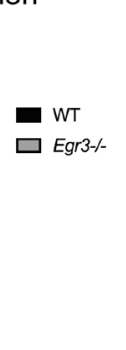

믈 ${ }_{\text {Egr3- }}^{\mathrm{w}}$
Male qRT PCR Fos expression

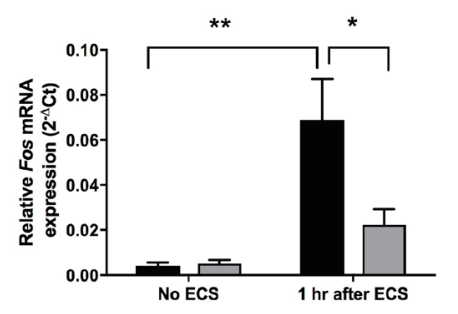

Cii

Male qRT PCR Fosb expression

\section{Replication qRT-PCR}

Aiii

Female qRT PCR Cenpa expression

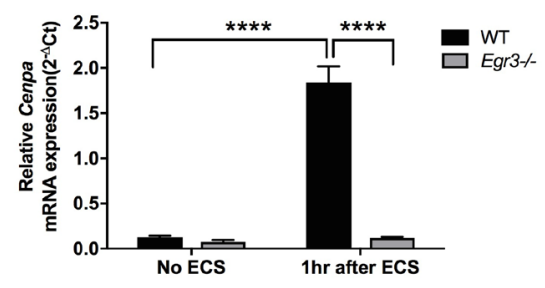

Biii

Female qRT PCR Fos expression

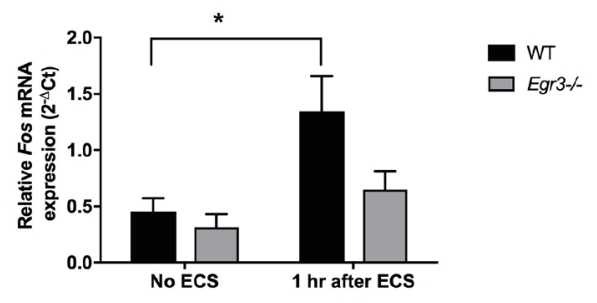

Ciii
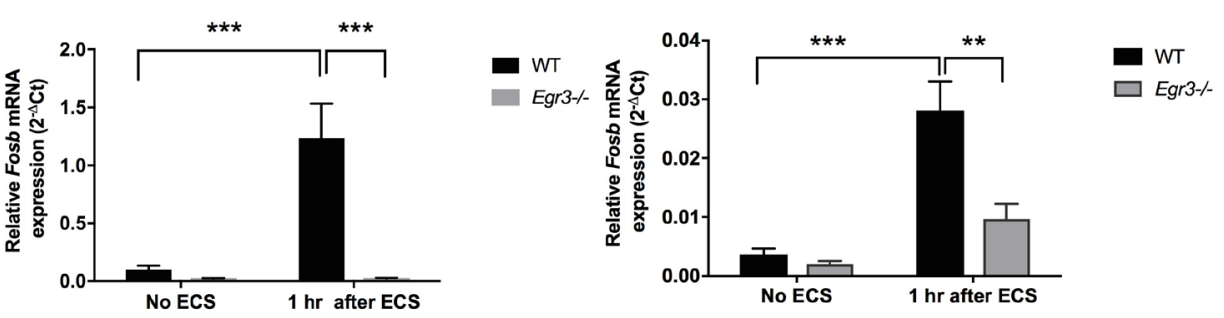

Di Male microarray Npas4 expression

Male qRT PCR Npas4 expression

Diii

Female qRT-PCR Npas4 expression
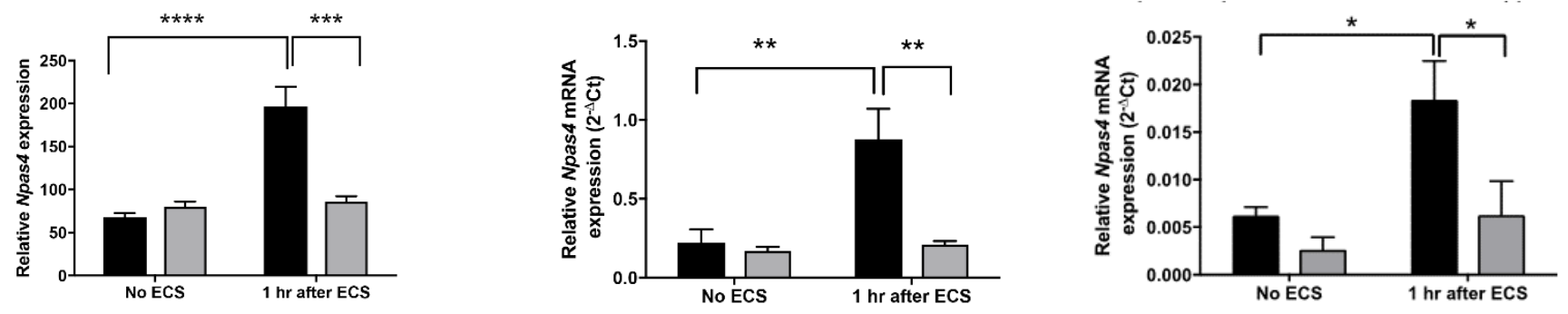

Ei

Male microarray Nr4a2 expression

Eii

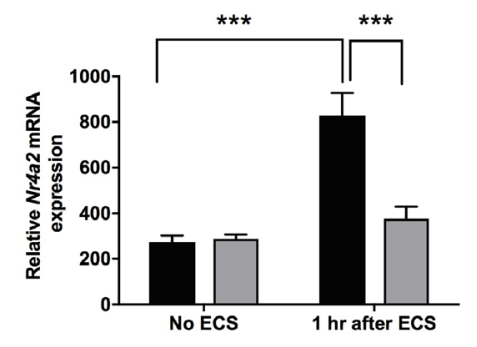

Male qRT PCR Nr4a2 expression

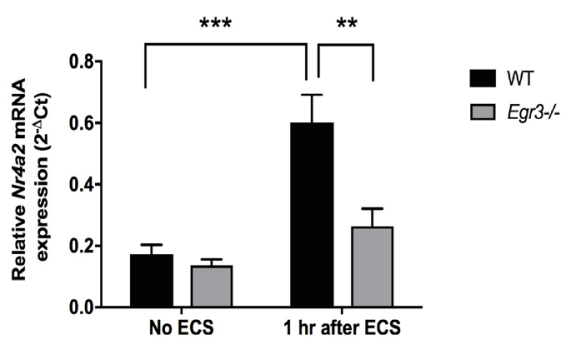

Female qRT PCR Nr4a2 expression

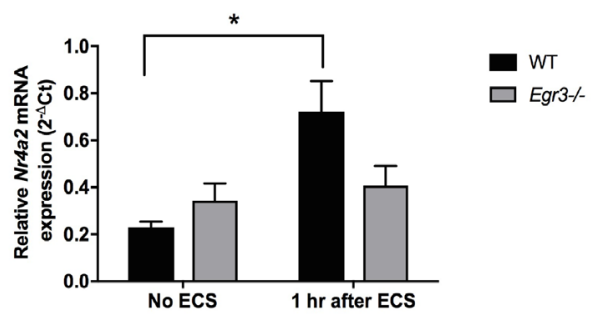


Figure 5

A. Microarray Mef2c expression

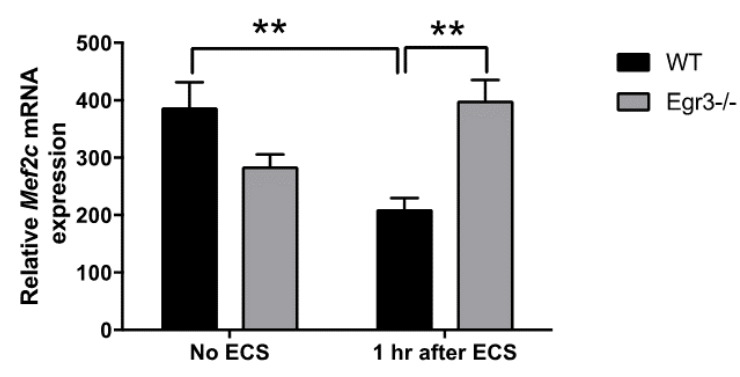

C. Microarray Calb2 expression

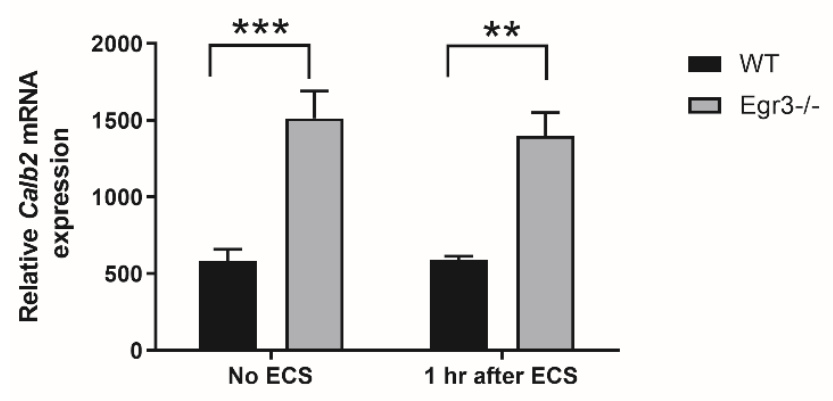

B. Male qRT-PCR Mef2c

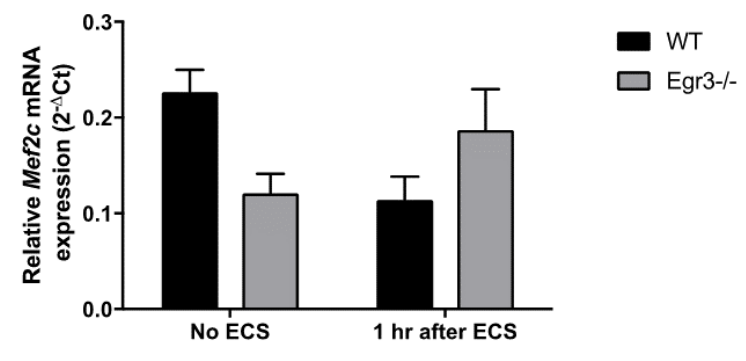

D. Male qRT-PCR Calb2

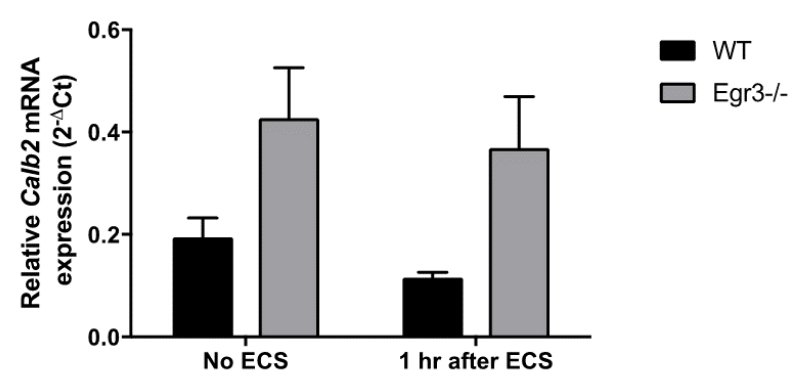


Table 1. Genes differentially expressed in the hippocampus of WT versus Egr3-/- mice following ECS.

71 genes showed a fold change difference of $\geq 1.4$ fold between the two groups with a $p$ value of $<0.05$.

\begin{tabular}{|c|c|c|c|}
\hline Gene & Protein & Diff score & $\begin{array}{c}\text { Fold change } \\
\text { (KO ECS/ WT ECS) }\end{array}$ \\
\hline Fosb & Protein fos $B$ & -335.914 & -10.69 \\
\hline$E G 244911$ & Uncharacterized protein & -335.914 & -9.94 \\
\hline A830030H1ORik & Riken clone & -335.914 & -6.16 \\
\hline LOC100046232 & Uncharacterized protein & -335.914 & -4.71 \\
\hline Cenpa & Histone H3-like centromeric protein A & -309.464 & -18.28 \\
\hline Gm484 & Netrin-5 & -266.84 & -6.79 \\
\hline Plk2 & Serine/threonine-protein kinase PLK2 & -252.231 & -2.65 \\
\hline Fbxo33 & F-box only protein 33 & -232.822 & -2.58 \\
\hline Grasp & GRIP1-associated protein 1 & -230.099 & -3.38 \\
\hline Pcdh8 & Protocadherin-8 & -202.238 & -5.44 \\
\hline Slc30a3 & Zinc transporter 3 & -199.839 & -4.73 \\
\hline Frmd6 & FERM domain-containing protein 6 & -185.239 & -2.29 \\
\hline Ras/10a & Ras-like protein family member $10 \mathrm{~A}$ & -170.502 & -2.71 \\
\hline Egr3 & Early growth response protein 3 & -167.957 & -6.89 \\
\hline $\operatorname{Arc}$ & Activity-regulated cytoskeleton-associated protein & -165.78 & -3.99 \\
\hline Sertad1 & SERTA domain-containing protein 1 & -165.07 & -3.96 \\
\hline Phf21b & PHD finger protein 21B & -154.007 & -2.49 \\
\hline $\mathrm{Nr} 4 a 2$ & Nuclear receptor subfamily 4 group A member 2 & -138.367 & -2.98 \\
\hline Camkk1 & Calcium/calmodulin-dependent protein kinase kinase 1 & -138.367 & -2.03 \\
\hline$C 1 q / 2$ & Complement C1q-like protein 2 & -133.754 & -6.53 \\
\hline A130062D16Rik & Riken clone & -130.955 & -2.05 \\
\hline$R p / 7 a$ & $60 S$ ribosomal protein $\mathrm{L} 7 \mathrm{a}$ & -123.122 & -2.41 \\
\hline Dusp4 & Dual specificity protein phosphatase 4 & -118.804 & -2.36 \\
\hline Gadd45g & Growth arrest and DNA damage-inducible protein GADD45 gamma & -108.553 & -2.15 \\
\hline Bag3 & BAG family molecular chaperone regulator 3 & -105.063 & -1.85 \\
\hline Per1 & Period circadian protein homolog 1 & -100.752 & -1.89 \\
\hline Ras/11a & Ras-like protein family member $11 \mathrm{~A}$ & -90.513 & -3.12 \\
\hline Fos & Proto-oncogene c-Fos & -80.709 & -2.4 \\
\hline Egr4 & Early growth response protein 4 & -79.594 & -2.49 \\
\hline 1700019N12Rik & Riken clone & -70.678 & -2.28 \\
\hline Npas4 & Neuronal PAS domain-containing protein 4 & -67.179 & -4.89 \\
\hline Slc25a25 & Calcium-binding mitochondrial carrier protein SCaMC-2 & -65.608 & -2.06 \\
\hline Nptx2 & Neuronal pentraxin-2 & -59.585 & -8.65 \\
\hline Coq10b & Coenzyme Q-binding protein COQ10 homolog B, mitochondrial & -56.113 & -1.92 \\
\hline Fos 12 & Fos-related antigen 2 & -53.18 & -2.397 \\
\hline
\end{tabular}




\begin{tabular}{|c|c|c|c|}
\hline 4932416C15Rik & Riken clone & -44.145 & -2.036 \\
\hline 1700086L19Rik & Riken clone & -43.796 & -2.69 \\
\hline Junb & Transcription factor jun-B & -43.317 & -2.44 \\
\hline Errfi1 & ERBB receptor feedback inhibitor 1 & -42.806 & -1.97 \\
\hline Dusp1 & Dual specificity protein phosphatase 1 & -40.162 & -2.04 \\
\hline$B d n f$ & Brain-derived neurotrophic factor & -39.862 & -3.25 \\
\hline$W f s 1$ & Wolframin & -36.559 & -1.9 \\
\hline Prox1 & Prospero homeobox protein 1 & -27.356 & -1.63 \\
\hline Psmb5 & Proteasome subunit beta type- 5 & -21.268 & -2.46 \\
\hline Gadd45b & Growth arrest and DNA damage-inducible protein GADD45 beta & -20.227 & -4.02 \\
\hline Gch1 & GTP cyclohydrolase 1 & -19.952 & -4.46 \\
\hline Dusp6 & Dual specificity protein phosphatase 6 & -19.707 & -1.47 \\
\hline Inhba & Inhibin beta A chain & -19.294 & -4.78 \\
\hline$C d k n 1 a$ & Cyclin-dependent kinase inhibitor 1 & -17.694 & -1.89 \\
\hline Cebpb & CCAAT/enhancer-binding protein beta & -16.31 & -2.54 \\
\hline 7030401E22Rik & Riken clone & -15.74 & -2.5 \\
\hline Dpp10 & Inactive dipeptidyl peptidase 10 & 15.407 & 1.78 \\
\hline Dlk1 & Protein delta homolog 1 & 17.775 & 3.71 \\
\hline Slc17a6 & Vesicular glutamate transporter 2 & 17.957 & 1.86 \\
\hline Calb2 & Calretinin & 23.033 & 1.96 \\
\hline Col6a1 & Collagen alpha-1(VI) chain & 23.071 & 2.17 \\
\hline Sstr2 & Somatostatin receptor type 2 & 24.086 & 2.56 \\
\hline 0610007P22Rik & Riken clone & 26.781 & 1.75 \\
\hline F630107L03Rik & Riken clone & 29.322 & 1.77 \\
\hline Cacng5 & Voltage-dependent calcium channel gamma-5 subunit & 43.34 & 2.25 \\
\hline Dpys/5 & Dihydropyrimidinase-related protein 5 & 52.13 & 4.12 \\
\hline
\end{tabular}




\section{Table 2. EGR3-dependent differentially expressed genes show altered expression in schizophrenia studies}

\begin{tabular}{|c|c|c|c|c|c|c|c|c|c|c|c|c|c|c|c|}
\hline $\begin{array}{l}\text { Gene } \\
\text { Symbol }\end{array}$ & Hits & $\begin{array}{l}\text { Total } \\
\text { Found }\end{array}$ & $\begin{array}{l}\text { Blood } \\
\text { mRNA }\end{array}$ & Deep & DISC1_RNA & $\begin{array}{l}\text { Gandal } \\
\text { Micro }\end{array}$ & $\begin{array}{l}\text { Gandal } \\
\text { RNAseq }\end{array}$ & $\begin{array}{l}\text { hiPSC } \\
\text { Neuron }\end{array}$ & $\begin{array}{l}\text { hiPSC } \\
\text { NPC1 }\end{array}$ & $\begin{array}{l}\text { MtSinai } \\
\text { ACC }\end{array}$ & $\begin{array}{l}\text { MtSinai } \\
\text { DLPFC }\end{array}$ & $\begin{array}{l}\text { MtSinai } \\
\text { MTA }\end{array}$ & $\begin{array}{l}\text { MtSinai } \\
\text { TPA }\end{array}$ & Stanley & Super \\
\hline ARC & 5 & 9 & $\begin{array}{l}F C=1.87 \\
\log F C=0.9 p\end{array}$ & $\begin{array}{l}F C=-1.02 \\
\operatorname{LogFC}=-0.03\end{array}$ & $\begin{array}{l}F C=2.54 \\
\log F C=1.34\end{array}$ & $\begin{array}{l}F C=-1.17 \\
\operatorname{LogFC}=-0.23\end{array}$ & $\begin{array}{l}F C=-1.37 \\
\log F C=-0.45\end{array}$ & $\begin{array}{l}F C=-1.11 \\
\log F=-0.15\end{array}$ & $\begin{array}{l}\mathrm{FC}=1.38 \\
\log \mathrm{FC}=0.47\end{array}$ & NA & NA & NA & NA & $\begin{array}{l}F C=-1.1 \\
\operatorname{LogFC}=-0.14\end{array}$ & $\begin{array}{l}F C=1.01 \\
\operatorname{LogFC}=0.02\end{array}$ \\
\hline AXUD1 & 0 & 1 & $=0.01$ & $p=0.82$ & $p=0.06$ & $p=0$ & $p=0.02$ & $p=0.67$ & $p=0.23$ & NA & NA & NA & NA & $\begin{array}{l}F C=-1.04 \\
\operatorname{LogFC}=-0.06 \\
p=0.57\end{array}$ & $p=0.91$ \\
\hline BAG3 & 8 & 14 & $\begin{array}{l}F C=1.02 \\
\operatorname{LogFC}=0.02 \\
p=0.89\end{array}$ & $\begin{array}{l}F C=-1 \operatorname{LogFC} \\
=-0.01 p= \\
0.96\end{array}$ & $\begin{array}{l}F C=-2.06 \\
\operatorname{LogFC}=- \\
1.04 p=0\end{array}$ & $\begin{array}{l}F C=1.38 \\
\log F C=0.46 \\
p=0\end{array}$ & $\begin{array}{l}F C=1.19 \\
\log F C=0.25 \\
p=0\end{array}$ & $\begin{array}{l}F C=-1.25 \\
\operatorname{LogFC}=-0.32 \\
p=0.08\end{array}$ & $\begin{array}{l}F C=-1.04 \\
\log F=-0.05 \\
p=0.8\end{array}$ & $\begin{array}{l}F C=-1.38 \\
\log F C=-0.46 \\
p=0.26\end{array}$ & $\begin{array}{l}F C=1.06 \\
\operatorname{LogFC}=0.08 \\
p=0.9\end{array}$ & $\begin{array}{l}F C=-1.18 \\
\log F C=-0.24 \\
p=0.42\end{array}$ & $\begin{array}{l}F C=-1.51 \\
\log F C=-0.59 \\
p=0.15\end{array}$ & $\begin{array}{l}F C=1.1 \\
\operatorname{LogFC}=0.13 \\
p=0.18\end{array}$ & $\begin{array}{l}F C=1.04 \\
\log F C=0.06 \\
p=0.61\end{array}$ \\
\hline BDNF & 8 & 13 & $\begin{array}{l}F C=1.04 \\
\operatorname{LogFC}=0.06 \\
p=0.7\end{array}$ & $\begin{array}{l}F C=-1.18 \\
\operatorname{LogFC}=-0.24 \\
p=0.04\end{array}$ & $\begin{array}{l}F C=-1.28 \\
\operatorname{LogFC}=- \\
0.35 p=0.68\end{array}$ & $\begin{array}{l}F C=-1.18 \\
\log F C=-0.24 \\
p=0\end{array}$ & $\begin{array}{l}F C=-1.22 \\
\operatorname{LogFC}=-0.28 \\
p=0.13\end{array}$ & $\begin{array}{l}F C=1.08 \\
\operatorname{LogFC}=0.12 \\
p=0.66\end{array}$ & $\begin{array}{l}F C=1.38 \\
\operatorname{LogFC}=0.47 \\
p=0.12\end{array}$ & $\begin{array}{l}F C=1.29 \\
\operatorname{LogFC}=0.37 p \\
=0.24\end{array}$ & $\begin{array}{l}F C=-1.15 \\
\log F C=-0.2 \\
p=0.61\end{array}$ & $\begin{array}{l}F C=1.12 \\
\operatorname{LogFC}=0.16 \\
p=0.66\end{array}$ & $\begin{array}{l}F C=1.31 \\
\log F C=0.39 p \\
=0.2\end{array}$ & $\begin{array}{l}F C=-1.02 \\
\operatorname{LogFC}=-0.03 \\
p=0.31\end{array}$ & $\begin{array}{l}\text { LogFC } \\
0.98\end{array}$ \\
\hline C1QL2 & 2 & 5 & $\begin{array}{l}F C=-1.72 \\
\operatorname{LogFC}=-0.78 \\
p=0.01\end{array}$ & $\begin{array}{l}F C=-1.09 \\
3 \operatorname{LogFC}=-0.13 \\
p=0.24\end{array}$ & $\begin{array}{l}F C=65.86 \\
\operatorname{LogFC}=6.04 \\
p=0\end{array}$ & NA & $\begin{array}{l}F C=-1.05 \\
\log F C=-0.07 \\
p=0.1\end{array}$ & NA & NA & NA & NA & NA & NA & NA & $\begin{array}{l}F C=-1.01 \\
\operatorname{LogFC}=-0.01 \\
p=0.93\end{array}$ \\
\hline CACNG5 & 0 & 7 & $\begin{array}{l}F C=1.04 \\
\operatorname{LogFC}=0.06 \\
p=0.59\end{array}$ & $\begin{array}{l}F C=1.01 \\
\operatorname{LogFC}=0.02 \\
p=0.83\end{array}$ & NA & $\begin{array}{l}F C=1 \operatorname{LogFC} \\
=0 p=0.87\end{array}$ & NA & $\begin{array}{l}F C=1.02 \\
\operatorname{LogFC}=0.03 \\
p=0.93\end{array}$ & $\begin{array}{l}F C=-1.05 \\
\operatorname{LogFC}=-0.07 \\
p=0.87\end{array}$ & NA & NA & NA & NA & $\begin{array}{l}F C=1.02 \\
\operatorname{LogFC}=0.03 \\
p=0.52\end{array}$ & $\begin{array}{l}F C=-1.07 \\
\operatorname{LogFC}=-0.09 \\
p=0.39\end{array}$ \\
\hline CALB2 & 6 & 12 & NA & $\begin{array}{l}F C=1.01 \\
\operatorname{LogFC}=0.02 \\
p=0.78\end{array}$ & $\begin{array}{l}F C=2.1 \\
\operatorname{LogFC}=1.07 \\
p=0.02\end{array}$ & $\begin{array}{l}F C=-1.04 \\
\log F C=-0.06 \\
p=0.1\end{array}$ & $\begin{array}{l}\log F C=-0.02 \\
p=0.65\end{array}$ & $\begin{array}{l}F C=-1.47 \\
\operatorname{LogFC}=-0.56 \\
p=0.23\end{array}$ & $\begin{array}{l}F C=1.72 \\
\operatorname{LogFC}=0.78 \\
p=0.17\end{array}$ & $\begin{array}{l}=0.38 p= \\
0.18\end{array}$ & $\begin{array}{l}F C=1.42 \\
\operatorname{LogFC}=0.51 \\
p=0.18\end{array}$ & $\begin{array}{l}\operatorname{LogFC}=-0.11 \\
p=0.59\end{array}$ & $\begin{array}{l}F C=1.39 \\
\operatorname{LogFC}=0.48 p \\
=0.03\end{array}$ & $\begin{array}{l}F C=-1.03 \\
\operatorname{LogFC}=-0.04 \\
p=0.53\end{array}$ & $\begin{array}{l}F C=1.01 \\
\operatorname{LogFC}=0.02 \\
p=0.87\end{array}$ \\
\hline САМКK1 & 4 & 12 & $\begin{array}{l}F C=-1.49 \\
\operatorname{LogFC}=-0.58 \\
p=0.03\end{array}$ & $\begin{array}{l}F C=1.01 \\
\operatorname{LogFC}=0.02 \\
p=0.78\end{array}$ & $\begin{array}{l}F C=1.68 \\
\operatorname{LogFC}=0.75 \\
p=0.01\end{array}$ & NA & $\begin{array}{l}F C=-1.02 \\
\log F C=-0.03 \\
p=0.24\end{array}$ & $\begin{array}{l}F C=1.09 \\
\log F C=0.12 \\
p=0.45\end{array}$ & $\begin{array}{l}F C=1.01 \\
\log F C=0.02 \\
p=0.92\end{array}$ & $\begin{array}{l}F C=1.2 \operatorname{LogFC} \\
=0.27 p= \\
0.18\end{array}$ & $\begin{array}{l}F C=-1.21 \\
\log F C=- \\
0.27 p=0.03\end{array}$ & $\begin{array}{l}F C=1.12 \\
\log F C=0.16 \\
p=0.36\end{array}$ & $\begin{array}{l}F C=1.03 \\
\log F C=0.04 p \\
=0.81\end{array}$ & $\begin{array}{l}F C=1.01 \\
\operatorname{LogFC}=0.02 \\
p=0.81\end{array}$ & $\begin{array}{l}F C=1.04 \\
\log F C=0.05 \\
p=0.59\end{array}$ \\
\hline CDKN1A & 8 & 14 & $\begin{array}{l}F C=-1.58 \\
\operatorname{LogFC}=-0.66 \\
p=0.04\end{array}$ & $\begin{array}{l}F C=1.08 \\
\operatorname{LogFC}=0.11 \\
p=0.17\end{array}$ & $\begin{array}{l}F C=-2.19 \\
\operatorname{LogFC}=- \\
1.13 p=0\end{array}$ & $\begin{array}{l}F C=1.02 \\
\log F C=0.03 \\
p=0.53\end{array}$ & $\begin{array}{l}F C=1.3 \\
\log F C=0.38 \\
p=0\end{array}$ & $\begin{array}{l}F C=1.44 \\
\operatorname{LogFC}=0.53 \\
p=0.12\end{array}$ & $\begin{array}{l}F C=-1.03 \\
\operatorname{LogFC}=-0.04 \\
p=0.9\end{array}$ & $\begin{array}{l}F C=-1.17 \\
\log F C=-0.22 \\
p=0.47\end{array}$ & $\begin{array}{l}F C=-1.04 \\
\operatorname{LogFC}=- \\
0.06 p=0.89\end{array}$ & $\begin{array}{l}F C=-1.25 \\
\log F C=-0.32 \\
p=0.52\end{array}$ & $\begin{array}{l}F C=-1.36 \\
\log F C=-0.44 \\
p=0.36\end{array}$ & $\begin{array}{l}F C=1.13 \\
\operatorname{LogFC}=0.17 \\
p=0.08\end{array}$ & $\begin{array}{l}F C=1.07 \\
\operatorname{LogFC}=0.1 p \\
=0.39\end{array}$ \\
\hline CEBPB & 8 & 13 & $\begin{array}{l}F C=-1.16 \\
\operatorname{LogFC}=-0.22 \\
p=0.29\end{array}$ & $\begin{array}{l}F C=-1.14 \\
\operatorname{LogFC}=-0.18 \\
p=0.2\end{array}$ & $\begin{array}{l}F C=-1.17 \\
\operatorname{LogFC}=- \\
0.23 p=0.66\end{array}$ & $\begin{array}{l}F C=1.06 \\
\log F C=0.08 \\
p=0.01\end{array}$ & $\begin{array}{l}F C=1.14 \\
\log F C=0.19 \\
p=0\end{array}$ & $\begin{array}{l}F C=1.16 \\
\operatorname{LogFC}=0.22 \\
p=0.42\end{array}$ & $\begin{array}{l}F C=-1 \operatorname{LogFC} \\
=0 p=1\end{array}$ & $\begin{array}{l}F C=-1.17 \\
\log F C=-0.23 \\
p=0.24\end{array}$ & $\begin{array}{l}F C=-1.06 \\
\log F C=- \\
0.08 p=0.69\end{array}$ & $\begin{array}{l}F C=-1.12 \\
\log F C=-0.17 \\
p=0.42\end{array}$ & $\begin{array}{l}F C=-1.31 \\
\log F C=-0.39 \\
p=0.09\end{array}$ & $\begin{array}{l}F C=1.05 \\
\operatorname{LogFC}=0.07 \\
p=0.32\end{array}$ & $\begin{array}{l}F C=1.21 \\
\log F C=0.27 \\
p=0.01\end{array}$ \\
\hline CENPA & 0 & 7 & $\begin{array}{l}F C=1.09 \\
\log F=0.12 \\
p=0.38\end{array}$ & $\begin{array}{l}F C=1.05 \\
\operatorname{LogFC}=0.07 \\
p=0.57\end{array}$ & NA & $\begin{array}{l}F C=-1.01 \\
\log F C=-0.02 \\
p=0.29\end{array}$ & NA & $\begin{array}{l}F C=-1.08 \\
\operatorname{LogFC}=-0.11 \\
p=0.67\end{array}$ & $\begin{array}{l}F C=1.02 \\
\log F=0.02 \\
p=0.91\end{array}$ & NA & NA & NA & NA & $\begin{array}{l}F C=1.02 \\
\operatorname{LogFC}=0.03 \\
p=0.42\end{array}$ & $\begin{array}{l}F C=-1.1 \\
\log F C=-0.13 \\
p=0.4\end{array}$ \\
\hline COL6A1 & 3 & 13 & $\begin{array}{l}F C=1.12 \\
\operatorname{LogFC}=0.17 \\
p=0.41\end{array}$ & $\begin{array}{l}F C=-1.13 \\
\operatorname{LogFC}=-0.17 \\
p=0.28\end{array}$ & $\begin{array}{l}F C=-1.48 \\
\operatorname{LogFC}=- \\
0.57 p=0.03\end{array}$ & $\begin{array}{l}F C=-1 \operatorname{LogFC} \\
=0 p=0.89\end{array}$ & $\begin{array}{l}F C=1.01 \\
\log F C=0.02 \\
p=0.59\end{array}$ & $\begin{array}{l}F C=-1.11 \\
\operatorname{LogFC}=-0.1 \\
p=0.27\end{array}$ & $\begin{array}{l}F C=-1.08 \\
\operatorname{LogFC}=-0.12 \\
p=0.4\end{array}$ & $\begin{array}{l}F C=-1.06 \\
\log F C=-0.09 \\
p=0.59\end{array}$ & $\begin{array}{l}F C=-1.22 \\
\log F C=- \\
0.29 p=0.08\end{array}$ & $\begin{array}{l}F C=1.07 \\
\operatorname{LogFC}=0.1 p \\
=0.45\end{array}$ & $\begin{array}{l}F C=1.2 \operatorname{LogFC} \\
=0.26 p= \\
0.04\end{array}$ & $\begin{array}{l}F C=1.01 \\
\operatorname{LogFC}=0.01 \\
p=0.21\end{array}$ & $\begin{array}{l}F C=1.11 \\
\log F C=0.15 \\
p=0.21\end{array}$ \\
\hline
\end{tabular}




\begin{tabular}{|c|c|c|c|c|c|c|c|c|c|c|c|c|c|c|c|}
\hline & & & $\mathrm{FC}=-1.33$ & $\mathrm{FC}=1.1$ & $\mathrm{FC}=1.17$ & $F C=-1.03$ & $F C=-1.05$ & $F C=-1.05$ & $\mathrm{FC}=-1.13$ & $F C=1.04$ & $F C=-1.01$ & $F C=-1.09$ & $F C=-1.09$ & & $\mathrm{FC}=1.51$ \\
\hline COQ10B & 5 & 12 & $\begin{array}{l}\operatorname{LogFC}=-0.41 \\
p=0.29\end{array}$ & $\begin{array}{l}\log F C=0.14 \\
p=0.15\end{array}$ & $\begin{array}{l}\log F C=0.23 \\
p=0.55\end{array}$ & $\begin{array}{l}\text { LogFC }=-0.05 \\
p=0.03\end{array}$ & $\begin{array}{l}\operatorname{LogFC}=-0.07 \\
p=0.03\end{array}$ & $\begin{array}{l}\log F C=-0.07 \\
p=0.56\end{array}$ & $\begin{array}{l}\log F C=-0.17 \\
p=0.19\end{array}$ & $\begin{array}{l}\operatorname{LogFC}=0.06 p \\
=0.56\end{array}$ & $\begin{array}{l}\log F C=- \\
0.02 p=0.79\end{array}$ & $\begin{array}{l}\log F C=-0.12 \\
p=0.21\end{array}$ & $\begin{array}{l}\log F C=-0.12 \\
p=0.25\end{array}$ & NA & $\begin{array}{l}\log F C=0.6 p \\
=0.03\end{array}$ \\
\hline CSRP2 & 6 & 12 & NA & $\begin{array}{l}F C=-1.04 \\
\operatorname{LogFC}=-0.05 \\
p=0.79\end{array}$ & $\begin{aligned} F C & =-1.55 \\
5 \operatorname{LogFC} & =- \\
0.63 p & =0.03\end{aligned}$ & $\begin{array}{l}F C=1.04 \\
\operatorname{LogFC}=0.06 \\
3 p=0.04\end{array}$ & $\begin{array}{l}F C=1.06 \\
\operatorname{LogFC}=0.09 \\
p=0.02\end{array}$ & $\begin{array}{l}F C=1.21 \\
\log F=0.27 \\
p=0.09\end{array}$ & $\begin{array}{l}F C=1.16 \\
\operatorname{LogFC}=0.21 \\
p=0.19\end{array}$ & $\begin{array}{l}F C=-1.08 \\
\log F C=-0.1 p \\
=0.6\end{array}$ & $\begin{array}{l}F C=1.05 \\
\operatorname{LogFC}=0.07 \\
p=0.72\end{array}$ & $\begin{array}{l}F C=1.37 \\
\operatorname{LogFC}=0.45 \\
p=0.12\end{array}$ & $\begin{array}{l}F C=1.06 \\
\operatorname{LogFC}=0.08 p \\
=0.66\end{array}$ & $\begin{array}{l}F C=1.02 \\
\log F C=0.03 \\
p=0.41\end{array}$ & $\begin{array}{l}F C=-1.05 \\
\operatorname{LogFC}=-0.07 \\
p=0.71\end{array}$ \\
\hline DLK1 & 5 & 9 & $\begin{array}{l}F C=-1.4 \\
\operatorname{LogFC}=-0.48 \\
p=0.02\end{array}$ & $\begin{array}{l}F C=-1.05 \\
\operatorname{LogFC}=-0.07 \\
p=0.65\end{array}$ & $\begin{array}{c}F C=-7.7 \\
7 \log F C=- \\
2.95 p=0\end{array}$ & $\begin{array}{l}F C=-1.01 \\
\log F C=-0.02 \\
p=0.33\end{array}$ & NA & $\begin{array}{l}F C=-1.77 \\
\log F C=-0.82 \\
p=0.15\end{array}$ & $\begin{array}{l}F C=-1.75 \\
\operatorname{LogFC}=-0.81 \\
p=0.28\end{array}$ & NA & NA & NA & NA & $\begin{array}{l}F C=1 \operatorname{LogFC} \\
=0 p=0.91\end{array}$ & $\begin{array}{l}F C=-1.05 \\
\operatorname{LogFC}=-0.06 \\
p=0.51\end{array}$ \\
\hline DPP10 & 5 & 10 & NA & $\begin{array}{l}F C=1.07 \\
\operatorname{LogFC}=0.1 p \\
=0.24\end{array}$ & p NA & NA & $\begin{array}{l}F C=-1.03 \\
\operatorname{LogFC}=-0.05 \\
p=0.03\end{array}$ & $\begin{array}{l}F C=1.32 \\
\log C=0.4 p \\
=0.39\end{array}$ & $\begin{array}{l}F C=1.24 \\
\operatorname{LogFC}=0.31 \\
p=0.55\end{array}$ & $\begin{array}{l}F C=1.19 \\
\operatorname{LogFC}=0.26 p \\
=0.27\end{array}$ & $\begin{array}{l}F C=-1.17 \\
\operatorname{LogFC}=- \\
0.22 p=0.25\end{array}$ & $\begin{array}{l}F C=-1.04 \\
\operatorname{LogFC}=-0.05 \\
p=0.78\end{array}$ & $\begin{array}{l}F C=1.07 \\
\operatorname{LogFC}=0.1 p \\
=0.58\end{array}$ & $\begin{array}{l}F C=-1 \operatorname{LogFC} \\
=0 p=0.9\end{array}$ & $\begin{array}{l}F C=1.1 \\
\operatorname{LogFC}=0.14 \\
p=0.4\end{array}$ \\
\hline DPYSL5 & 3 & 12 & NA & $\begin{array}{l}F C=1 \operatorname{LogFC} \\
=0.01 p= \\
0.96\end{array}$ & $\begin{array}{l}F C=1.53 \\
\log F C=0.61 \\
p=0.05\end{array}$ & NA & $\begin{array}{l}F C=-1 \log F C \\
=0 p=0.99\end{array}$ & $\begin{array}{l}F C=-1.05 \\
\operatorname{LogFC}=-0.08 \\
p=0.54\end{array}$ & $\begin{array}{l}F C=-1.01 \\
\operatorname{LogFC}=-0.01 \\
p=0.91\end{array}$ & $\begin{array}{l}F C=-1.09 \\
\log F C=-0.13 \\
p=0.51\end{array}$ & $\begin{array}{l}F C=1.07 \\
\operatorname{LogFC}=0.1 p \\
=0.72\end{array}$ & $\begin{array}{l}F C=1.1 \\
\operatorname{LogFC}=0.14 \\
p=0.39\end{array}$ & $\begin{array}{l}F C=-1.01 \\
\log F C=-0.01 \\
p=0.91\end{array}$ & $\begin{array}{l}F C=-1.11 \\
\log F C=-0.15 \\
p=0.02\end{array}$ & $\begin{array}{l}F C=-1.01 \\
\operatorname{LogFC}=-0.01 \\
p=0.9\end{array}$ \\
\hline DUSP1 & 7 & 13 & $\begin{array}{l}F C=-1.15 \\
\log F=-0.2 \\
p=0.18\end{array}$ & $\begin{array}{l}F C=-1.01 \\
\operatorname{LogFC}=-0.02 \\
p=0.77\end{array}$ & $\begin{array}{l}F C=1.07 \\
2 \operatorname{LogFC}=0.09 \\
p=0.77\end{array}$ & $\begin{array}{l}F C=-1.25 \\
\log F C=-0.33 \\
p=0\end{array}$ & $\begin{array}{l}F C=-1.23 \\
\log F C=-0.3 \\
p=0.05\end{array}$ & $\begin{array}{l}F C=-1.19 \\
\log F C=-0.26 \\
p=0.21\end{array}$ & $\begin{array}{l}F C=1.12 \\
\log F=0.17 \\
p=0.43\end{array}$ & $\begin{array}{l}F C=1.2 \log F C \\
=0.26 p=0.4\end{array}$ & $\begin{array}{l}F C=-1.01 \\
\log F C=- \\
0.01 p=0.98\end{array}$ & $\begin{array}{l}F C=1.22 \\
\operatorname{LogFC}=0.28 \\
p=0.36\end{array}$ & $\begin{array}{l}F C=-1.24 \\
\log F C=-0.31 \\
p=0.25\end{array}$ & $\begin{array}{l}F C=-1.05 \\
\log F C=-0.07 \\
p=0.25\end{array}$ & $\begin{array}{l}F C=1 \operatorname{LogFC} \\
=0 p=0.98\end{array}$ \\
\hline DUSP4 & 4 & 9 & $\begin{array}{l}F C=3.38 \\
\operatorname{LogFC}=1.76 \\
p=0\end{array}$ & $\begin{array}{l}F C=-1.01 \\
\operatorname{LogFC}=-0.02 \\
p=0.74\end{array}$ & $\begin{array}{l}F C=1.67 \\
2 \operatorname{LogFC}=0.74 \\
p=0.02\end{array}$ & $\begin{array}{l}F C=-1.11 \\
\log F C=-0.15 \\
p=0\end{array}$ & $\begin{array}{l}F C=-1.35 \\
\log F C=-0.43 \\
p=0.09\end{array}$ & $\begin{array}{l}F C=1.02 \\
\log F C=0.02 \\
p=0.91\end{array}$ & $\begin{array}{l}F C=-1.11 \\
\operatorname{LogFC}=-0.15 \\
p=0.46\end{array}$ & NA & NA & NA & NA & $\begin{array}{l}F C=-1.05 \\
\log F C=-0.08 \\
p=0.08\end{array}$ & $\begin{array}{l}F C=-1.09 \\
\log F C=-0.13 \\
p=0.18\end{array}$ \\
\hline DUSP6 & 7 & 13 & $\begin{array}{l}F C=-1.63 \\
\operatorname{LogFC}=-0.71 \\
p=0.07\end{array}$ & $\begin{array}{l}F C=-1.11 \\
\operatorname{LogFC}=-0.15 \\
p=0.29\end{array}$ & $\begin{array}{c}F C=-2.42 \\
5 \operatorname{LogFC}=- \\
1.28 p=0\end{array}$ & $\begin{array}{l}F C=-1.21 \\
\operatorname{LogFC}=-0.27 \\
p=0\end{array}$ & $\begin{array}{l}F C=-1.23 \\
\log F C=-0.3 \\
p=0.1\end{array}$ & $\begin{array}{l}F C=1.04 \\
\log F C=0.06 \\
p=0.86\end{array}$ & $\begin{array}{l}F C=1 \operatorname{LogFC} \\
=0.01 p= \\
0.98\end{array}$ & $\begin{array}{l}F C=1.12 \\
\operatorname{LogFC}=0.16 p \\
=0.4\end{array}$ & $\begin{array}{l}F C=1.18 \\
\operatorname{LogFC}=0.24 \\
p=0.25\end{array}$ & $\begin{array}{l}F C=1.21 \\
\operatorname{LogFC}=0.28 \\
p=0.17\end{array}$ & $\begin{array}{l}F C=-1.07 \\
\log F C=-0.1 p \\
=0.73\end{array}$ & $\begin{array}{l}F C=-1.1 \\
\log F C=-0.13 \\
p=0.03\end{array}$ & $\begin{array}{l}F C=-1.11 \\
\operatorname{LogFC}=-0.15 \\
p=0.26\end{array}$ \\
\hline DYRK3 & 2 & 9 & $\begin{array}{l}F C=1.07 \\
\operatorname{LogFC}=0.1 p \\
=0.59\end{array}$ & $\begin{array}{l}F C=-1.03 \\
\operatorname{LogFC}=-0.05 \\
p=0.7\end{array}$ & $\begin{array}{l}F C=-1.46 \\
5 \operatorname{LogFC}=- \\
0.54 p=0.06\end{array}$ & $\begin{array}{l}F C=1.02 \\
\operatorname{LogFC}=0.02 \\
p=0.21\end{array}$ & $\begin{array}{l}F C=-1.01 \\
\log F C=-0.01 \\
p=0.93\end{array}$ & $\begin{array}{l}F C=1.03 \\
\log F C=0.04 \\
p=0.82\end{array}$ & $\begin{array}{l}F C=1.18 \\
\operatorname{LogFC}=0.24 \\
p=0.2\end{array}$ & NA & NA & NA & NA & $\begin{array}{l}F C=-1.01 \\
\operatorname{LogFC}=-0.01 \\
p=0.6\end{array}$ & $\begin{array}{l}F C=1.03 \\
\operatorname{LogFC}=0.05 \\
p=0.64\end{array}$ \\
\hline EGR3 & 5 & 13 & $\begin{array}{l}F C=1.32 \\
\log F C=0.4 p\end{array}$ & $\begin{array}{l}F C=1.06 \\
\log F C=0.08\end{array}$ & $\begin{array}{l}\mathrm{FC}=3.12 \\
\log F C=1.64\end{array}$ & $\begin{array}{l}F C=-1.07 \\
\log F C=-0.1 p\end{array}$ & $\begin{array}{l}F C=-1.09 \\
\log F C=-0.12\end{array}$ & $\begin{array}{l}F C=-1.09 \\
\log F C=-0.12\end{array}$ & $\begin{array}{l}\mathrm{FC}=1.37 \\
\log \mathrm{FC}=0.46\end{array}$ & $\begin{array}{l}F C=1.17 \\
\log F C=0.23 p\end{array}$ & $\begin{array}{l}F C=1.02 \\
\log F C=0.03\end{array}$ & $\begin{array}{l}F C=-1.04 \\
\log F C=-0.05\end{array}$ & $\begin{array}{l}F C=-1.11 \\
\log F C=-0.15\end{array}$ & $\begin{array}{l}F C=-1.06 \\
\log F C=-0.08\end{array}$ & $\begin{array}{l}F C=1.06 \\
\log F C=0.08\end{array}$ \\
\hline & & & $=0.43$ & $p=0.38$ & $p=0$ & $=0$ & $p=0.15$ & $p=0.74$ & $p=0.24$ & $=0.27$ & $p=0.89$ & $p=0.8$ & $p=0.56$ & $p=0.15$ & $p=0.43$ \\
\hline EGR4 & 7 & 10 & NA & $\begin{array}{l}F C=1 \operatorname{LogFC} \\
=0 p=0.98\end{array}$ & $\begin{array}{l}F C=1.96 \\
\operatorname{LogFC}=0.97 \\
p=0.31\end{array}$ & $\begin{array}{l}F C=-1.15 \\
\log F C=-0.2 p \\
=0\end{array}$ & $\begin{array}{l}F C=-1.25 \\
\operatorname{LogFC}=-0.32 \\
p=0.02\end{array}$ & NA & NA & $\begin{array}{l}F C=1.19 \\
\log F C=0.25 p \\
=0.4\end{array}$ & $\begin{array}{l}F C=-1.02 \\
\log F C=- \\
0.03 p=0.94\end{array}$ & $\begin{array}{l}F C=1.26 \\
\operatorname{LogFC}=0.34 \\
p=0.17\end{array}$ & $\begin{array}{l}F C=-1.8 \\
\operatorname{LogFC}=-0.85 \\
p=0.24\end{array}$ & $\begin{array}{l}F C=-1.1 \\
\log F C=-0.14 \\
p=0.03\end{array}$ & $\begin{array}{l}F C=-1.09 \\
\log F C=-0.12 \\
p=0.34\end{array}$ \\
\hline EMD & 1 & 9 & $\begin{array}{l}F C=-1.03 \\
\operatorname{LogFC}=-0.04 \\
p=0.78\end{array}$ & $\begin{array}{l}F C=1.05 \\
\operatorname{LogFC}=0.07 \\
p=0.26\end{array}$ & $\begin{array}{l}F C=-1.29 \\
\operatorname{LogFC}=- \\
0.37 p=0.07\end{array}$ & $\begin{array}{l}F C=-1.02 \\
\operatorname{LogFC}=-0.02 \\
7 p=0.11\end{array}$ & $\begin{array}{l}F C=1.03 \\
\operatorname{LogFC}=0.05 \\
p=0.46\end{array}$ & $\begin{array}{l}F C=-1.05 \\
\log F=-0.07 \\
p=0.5\end{array}$ & $\begin{array}{l}F C=1.06 \\
\log F C=0.08 \\
p=0.45\end{array}$ & NA & NA & NA & NA & $\begin{array}{l}F C=1.02 \\
\log F C=0.02 \\
p=0.58\end{array}$ & $\begin{array}{l}F C=1.11 \\
\log F C=0.15 \\
p=0.22\end{array}$ \\
\hline ERRFI1 & 5 & 11 & $\begin{array}{l}F C=1.4 \\
\operatorname{LogFC}=0.49 \\
p=0.01\end{array}$ & $\begin{array}{l}F C=1.06 \\
\operatorname{LogFC}=0.08 \\
p=0.31\end{array}$ & $\begin{array}{l}F C=-1.59 \\
\operatorname{LogFC}=- \\
0.66 p=0.04\end{array}$ & NA & $\begin{array}{l}F C=1.01 \\
\operatorname{LogFC}=0.01 \\
p=0.67\end{array}$ & $\begin{array}{l}F C=1.12 \\
\operatorname{LogFC}=0.17 \\
p=0.69\end{array}$ & $\begin{array}{l}F C=-1.36 \\
\operatorname{LogFC}=-0.45 \\
p=0.3\end{array}$ & $\begin{array}{l}F C=-1.06 \\
\log F C=-0.08 \\
p=0.53\end{array}$ & $\begin{array}{l}F C=1.01 \\
\operatorname{LogFC}=0.02 \\
p=0.9\end{array}$ & $\begin{array}{l}F C=1.03 \\
\operatorname{LogFC}=0.04 \\
p=0.49\end{array}$ & $\begin{array}{l}F C=-1.18 \\
\log F C=-0.24 \\
p=0.12\end{array}$ & NA & $\begin{array}{l}F C=1.15 \\
\operatorname{LogFC}=0.2 p \\
=0.19\end{array}$ \\
\hline FBXO33 & 4 & 12 & $\begin{array}{l}F C=-1.34 \\
\operatorname{LogFC}=-0.42 \\
p=0.17\end{array}$ & $\begin{array}{l}F C=-1.02 \\
\log F C=-0.03 \\
p=0.78\end{array}$ & $\begin{array}{c}F C=-1.11 \\
3 \operatorname{LogFC}=- \\
0.15 p=0.6\end{array}$ & NA & $\begin{array}{l}F C=-1.03 \\
\log F C=-0.04 \\
p=0.19\end{array}$ & $\begin{array}{l}F C=-1.05 \\
\log F C=-0.08 \\
p=0.31\end{array}$ & $\begin{array}{l}F C=-1.01 \\
\log F C=-0.01 \\
p=0.87\end{array}$ & $\begin{array}{l}F C=-1.21 \\
\log F C=-0.27 \\
p=0.17\end{array}$ & $\begin{array}{l}F C=1.07 \\
\log F C=0.1 p \\
=0.45\end{array}$ & $\begin{array}{l}F C=1.31 \\
\log C=0.39 \\
p=0.01\end{array}$ & $\begin{array}{l}F C=1.45 \\
\log F C=0.54 p \\
=0.01\end{array}$ & $\begin{array}{l}F C=1.01 \\
\log F C=0.02 \\
p=0.15\end{array}$ & $\begin{array}{l}F C=1 \operatorname{LogFC} \\
=0 p=1\end{array}$ \\
\hline
\end{tabular}




\begin{tabular}{|c|c|c|c|c|c|c|c|c|c|c|c|c|c|c|c|}
\hline \multirow{3}{*}{ FOS } & \multirow{3}{*}{8} & \multirow{3}{*}{13} & $F C=-1.57$ & $F C=-1.05$ & $F C=-1.5$ & $\mathrm{FC}=-$ & $F C=-1.29$ & $=1.01$ & $\mathrm{FC}=1.47$ & $\mathrm{FC}=1.34$ & $F C=-2.21$ & \multirow{3}{*}{$\begin{array}{l}F C=1.08 \\
\log F C=0.11 \\
p=0.81\end{array}$} & \multirow{3}{*}{$\begin{array}{l}F C=-1.91 \\
\log F C=-0.94 \\
p=0.23\end{array}$} & \multirow{3}{*}{$\begin{array}{l}F C=-1.09 \\
\operatorname{LogFC}=-0.12 \\
p=0.09\end{array}$} & \multirow{3}{*}{$\begin{array}{l}F C=1.09 \\
\log F C=0.13\end{array}$} \\
\hline & & & $\log F C=-0.65$ & $\operatorname{LogFC}=-0.07$ & 7 LogFC = - & $\log F C=-0.36$ & $\log F C=-0.37$ & $\log F C=0.02$ & $\log F C=0.56$ & $\log F C=0.42 p$ & LogFC = - & & & & \\
\hline & & & $p=0.13$ & $p=0.39$ & $0.59 p=0.03$ & $3 p=0$ & $p=0.11$ & $p=0.95$ & $p=0.14$ & $=0.42$ & $1.15 p=0.39$ & & & & \\
\hline FOSB & 4 & 8 & NA & $\begin{array}{l}F C=1.09 \\
\operatorname{LogFC}=0.12\end{array}$ & $\begin{array}{l}F C=3.06 \\
\log F C=1.61\end{array}$ & $\begin{array}{l}F C=-1.02 \\
\log F C=-0.03\end{array}$ & $\begin{array}{l}F C=-1.06 \\
\log F C=-0.09\end{array}$ & $\begin{array}{l}F C=-1.52 \\
\log F C=-0.6\end{array}$ & $\begin{array}{l}F C=1.48 \\
\operatorname{LogFC}=0.56\end{array}$ & NA & NA & NA & NA & $\begin{array}{l}F C=-1.01 \\
\operatorname{LogFC}=-0.02\end{array}$ & $\begin{array}{l}F C=-1.15 \\
\log F=-0.2\end{array}$ \\
\hline & & & & $p=0.18$ & $p=0.05$ & $p=0.5$ & $p=0.3$ & $p=0.16$ & $p=0.22$ & & & & & $p=0.64$ & $p=0.17$ \\
\hline FOSL2 & 4 & 12 & NA & $\begin{array}{l}F C=1.09 \\
\operatorname{LogFC}=0.13 \\
p=0.15\end{array}$ & $\begin{array}{l}F C=3.34 \\
\operatorname{LogFC}=1.74 \\
p=0\end{array}$ & $\begin{array}{l}F C=1 \operatorname{LogFC} \\
=0.01 p= \\
0.87\end{array}$ & $\begin{array}{l}F C=1.01 \\
\log F C=0.01 \\
p=0.9\end{array}$ & $\begin{array}{l}F C=-1.23 \\
\log F C=-0.3 \\
p=0.17\end{array}$ & $\begin{array}{l}F C=1.01 \\
\operatorname{LogFC}=0.01 \\
p=0.96\end{array}$ & $\begin{array}{l}F C=-1.01 \\
\log F C=-0.01 \\
p=0.95\end{array}$ & $\begin{array}{l}F C=-1.42 \\
\operatorname{LogFC}=-0.5 \\
p=0.02\end{array}$ & $\begin{array}{l}F C=-1.05 \\
\log F C=-0.06 \\
p=0.73\end{array}$ & $\begin{array}{l}F C=-1.34 \\
\log F C=-0.42 \\
p=0.17\end{array}$ & $\begin{array}{l}F C=-1.01 \\
\operatorname{LogFC}=-0.01 \\
p=0.64\end{array}$ & $\begin{array}{l}F C=-1.1 \\
\operatorname{LogFC}=-0.14 \\
p=0.21\end{array}$ \\
\hline FRMD6 & 3 & 11 & $\begin{array}{l}F C=-1.4 \\
\operatorname{LogFC}=-0.49 \\
p=0.13\end{array}$ & $\begin{array}{l}F C=1.05 \\
\operatorname{LogFC}=0.07 \\
p=0.32\end{array}$ & $\begin{array}{l}F C=-3.16 \\
\operatorname{LogFC}=- \\
1.66 p=0\end{array}$ & NA & $\begin{array}{l}F C=-1.09 \\
\operatorname{LogFC}=-0.12 \\
p=0\end{array}$ & $\begin{array}{l}F C=1.05 \\
\log F C=0.07 \\
p=0.66\end{array}$ & $\begin{array}{l}F C=1.09 \\
\operatorname{LogFC}=0.12 \\
p=0.39\end{array}$ & $\begin{array}{l}F C=1.03 \\
\operatorname{LogFC}=0.04 p \\
=0.82\end{array}$ & $\begin{array}{l}F C=-1.02 \\
\log F C=- \\
0.03 p=0.88\end{array}$ & $\begin{array}{l}F C=1.1 \\
\operatorname{LogFC}=0.14 \\
p=0.29\end{array}$ & $\begin{array}{l}F C=1.07 \\
\operatorname{LogFC}=0.09 p \\
=0.53\end{array}$ & NA & $\begin{array}{l}F C=-1.07 \\
\log F C=-0.09 \\
p=0.34\end{array}$ \\
\hline GADD45B & 8 & 13 & $\begin{array}{l}F C=-1.09 \\
\log F=-0.12 \\
p=0.56\end{array}$ & $\begin{array}{l}F C=1.04 \\
\operatorname{LogFC}=0.06 \\
p=0.69\end{array}$ & $\begin{array}{l}F C=-1.37 \\
\log F C=- \\
0.45 p=0.53\end{array}$ & $\begin{array}{l}F C=1.1 \\
\log F C=0.13 \\
p=0.03\end{array}$ & $\begin{array}{l}F C=1.24 \\
\log F C=0.31 \\
p=0\end{array}$ & $\begin{array}{l}F C=-1.29 \\
\operatorname{LogFC}=-0.36 \\
p=0.24\end{array}$ & $\begin{array}{l}F C=1.13 \\
\operatorname{LogFC}=0.17 \\
p=0.59\end{array}$ & $\begin{array}{l}F C=-1.26 \\
\log F C=-0.33 \\
p=0.25\end{array}$ & $\begin{array}{l}F C=-2.07 \\
\operatorname{LogFC}=- \\
1.05 p=0.25\end{array}$ & $\begin{array}{l}F C=-1.81 \\
\log F C=-0.85 \\
p=0.14\end{array}$ & $\begin{array}{l}F C=-2.55 \\
\log F C=-1.35 \\
p=0.1\end{array}$ & $\begin{array}{l}F C=1.05 \\
\operatorname{LogFC}=0.07 \\
p=0.08\end{array}$ & $\begin{array}{l}F C=1.12 \\
\operatorname{LogFC}=0.16 \\
p=0.19\end{array}$ \\
\hline GADD45G & 5 & 9 & $\begin{array}{l}F C=1.45 \\
\operatorname{LogFC}=0.54 \\
p=0.11\end{array}$ & $\begin{array}{l}F C=-1.18 \\
\operatorname{LogFC}=-0.24 \\
p=0.09\end{array}$ & $\begin{array}{l}F C=2.31 \\
4 \operatorname{LogFC}=1.21 \\
p=0\end{array}$ & $\begin{array}{l}F C=1.04 \\
\log F C=0.05 \\
p=0.12\end{array}$ & $\begin{array}{l}F C=1.2 \\
\operatorname{LogFC}=0.27 \\
p=0\end{array}$ & $\begin{array}{l}F C=1.11 \\
\log F C=0.15 \\
p=0.67\end{array}$ & $\begin{array}{l}F C=1.15 \\
\operatorname{LogFC}=0.2 p \\
=0.55\end{array}$ & NA & NA & NA & NA & $\begin{array}{l}F C=1.04 \\
\operatorname{LogFC}=0.06 \\
p=0.3\end{array}$ & $\begin{array}{l}F C=1.06 \\
\operatorname{LogFC}=0.09 \\
p=0.51\end{array}$ \\
\hline GCH1 & 8 & 12 & $\begin{array}{l}F C=-1.08 \\
\operatorname{LogFC}=-0.12 \\
p=0.53\end{array}$ & $\begin{array}{l}F C=-1.15 \\
\operatorname{LogFC}=-0.2 \\
p=0.03\end{array}$ & NA & $\begin{array}{l}F C=-1.08 \\
\log F C=-0.11 \\
p=0\end{array}$ & $\begin{array}{l}F C=-1.01 \\
\operatorname{LogFC}=-0.01 \\
p=0.8\end{array}$ & $\begin{array}{l}F C=-1.15 \\
\log F C=-0.2 \\
p=0.52\end{array}$ & $\begin{array}{l}F C=-1.34 \\
\log F C=-0.43 \\
p=0.19\end{array}$ & $\begin{array}{l}F C=-1.49 \\
\log F C=-0.58 \\
p=0.13\end{array}$ & $\begin{array}{l}F C=1.53 \\
\log F=0.61 \\
p=0.23\end{array}$ & $\begin{array}{l}F C=1.07 \\
\operatorname{LogFC}=0.1 p \\
=0.71\end{array}$ & $\begin{array}{l}F C=-1.33 \\
\log F C=-0.41 \\
p=0.21\end{array}$ & $\begin{array}{l}F C=-1.03 \\
\operatorname{LogFC}=-0.05 \\
p=0.26\end{array}$ & $\begin{array}{l}F C=1.17 \\
\log F C=0.23 \\
p=0.14\end{array}$ \\
\hline GRASP & 5 & 12 & $\begin{array}{l}F C=-1.01 \\
\log F C=-0.01\end{array}$ & $\begin{array}{l}F C=1.02 \\
\log F C=0.03\end{array}$ & $\begin{array}{l}F C=3.12 \\
\log F C=1.64\end{array}$ & NA & $\begin{array}{l}F C=-1.11 \\
\log F C=-0.15\end{array}$ & $\begin{array}{l}F C=1.03 \\
\log F C=0.05\end{array}$ & $\begin{array}{l}F C=-1.11 \\
\operatorname{LogFC}=-0.15\end{array}$ & $\begin{array}{l}F C=1.23 \\
\log F C=0.29 p\end{array}$ & $\begin{array}{l}F C=-1.1 \\
\log F C=-\end{array}$ & $\begin{array}{l}F C=1.15 \\
\log F C=0.2 p\end{array}$ & $\begin{array}{l}F C=1.15 \\
\log F C=0.2 p\end{array}$ & $\begin{array}{l}F C=-1.01 \\
\operatorname{LogFC}=-0.01\end{array}$ & $\begin{array}{l}F C=1.06 \\
\log F C=0.08\end{array}$ \\
\hline & & & $p=0.94$ & $p=0.83$ & $p=0.01$ & & $p=0.03$ & $p=0.82$ & $p=0.47$ & $=0.18$ & $0.14 p=0.36$ & $=0.19$ & $=0.3$ & $p=0.79$ & $p=0.42$ \\
\hline INHBA & 4 & 8 & NA & $\begin{array}{l}F C=1.05 \\
\operatorname{LogFC}=0.07 \\
p=0.31\end{array}$ & $\begin{array}{l}F C=-1.29 \\
\operatorname{LogFC}=- \\
0.37 p=0.58\end{array}$ & $\begin{array}{l}F C=-1.03 \\
\log F C=-0.04 \\
p=0.08\end{array}$ & $\begin{array}{l}F C=-1.08 \\
\operatorname{LogFC}=-0.11 \\
p=0.58\end{array}$ & $\begin{array}{l}F C=1.46 \\
\operatorname{LogFC}=0.54 \\
p=0.37\end{array}$ & $\begin{array}{l}F C=1.17 \\
\operatorname{LogFC}=0.23 \\
p=0.75\end{array}$ & NA & NA & NA & NA & $\begin{array}{l}F C=-1.01 \\
\operatorname{LogFC}=-0.02 \\
p=0.45\end{array}$ & $\begin{array}{l}F C=-1.34 \\
\operatorname{LogFC}=-0.42 \\
p=0.01\end{array}$ \\
\hline JUNB & 5 & 13 & $\begin{array}{l}F C=-1.27 \\
\operatorname{LogFC}=-0.34 \\
p=0.08\end{array}$ & $\begin{array}{l}F C=1.08 \\
\operatorname{LogFC}=0.12 \\
p=0.11\end{array}$ & $\begin{array}{l}F C=-1.21 \\
\operatorname{LogFC}=- \\
0.28 p=0.56\end{array}$ & $\begin{array}{l}F C=-1.13 \\
\log F C=-0.17 \\
p=0\end{array}$ & $\begin{array}{l}F C=-1.06 \\
\operatorname{LogFC}=-0.08 \\
p=0.46\end{array}$ & $\begin{array}{l}F C=1.01 \\
\operatorname{LogFC}=0.02 \\
p=0.94\end{array}$ & $\begin{array}{l}F C=1.08 \\
\operatorname{LogFC}=0.11 \\
p=0.65\end{array}$ & $\begin{array}{l}F C=1.13 \\
\operatorname{LogFC}=0.18 p \\
=0.49\end{array}$ & $\begin{array}{l}F C=-1.32 \\
\operatorname{LogFC}=-0.4 \\
p=0.5\end{array}$ & $\begin{array}{l}F C=1.12 \\
\log F C=0.16 \\
p=0.49\end{array}$ & $\begin{array}{l}F C=-1.4 \\
\log F C=-0.48 \\
p=0.27\end{array}$ & $\begin{array}{l}F C=1.01 \\
\operatorname{LogFC}=0.01 \\
p=0.89\end{array}$ & $\begin{array}{l}F C=-1.04 \\
\operatorname{LogFC}=-0.06 \\
p=0.47\end{array}$ \\
\hline KCTD4 & 3 & 10 & NA & $\begin{array}{l}F C=-1.04 \\
\operatorname{LogFC}=-0.06 \\
p=0.4\end{array}$ & $6 \mathrm{NA}$ & NA & $\begin{array}{l}F C=-1.08 \\
\log F C=-0.12 \\
p=0\end{array}$ & $\begin{array}{l}F C=-1.05 \\
\operatorname{LogFC}=-0.07 \\
p=0.79\end{array}$ & $\begin{array}{l}F C=1.05 \\
\log F=0.08 \\
p=0.79\end{array}$ & $\begin{array}{l}F C=-1.09 \\
\log F C=-0.13 \\
p=0.43\end{array}$ & $\begin{array}{l}F C=1.23 \\
\operatorname{LogFC}=0.29 \\
p=0.55\end{array}$ & $\begin{array}{l}F C=-1.25 \\
\log F C=-0.32 \\
p=0.2\end{array}$ & $\begin{array}{l}F C=-1.05 \\
\log F C=-0.07 \\
p=0.8\end{array}$ & $\begin{array}{l}F C=-1.08 \\
\operatorname{LogFC}=-0.11 \\
p=0.24\end{array}$ & $\begin{array}{l}F C=-1.13 \\
\operatorname{LogFC}=-0.17 \\
p=0.17\end{array}$ \\
\hline LINGO1 & 4 & 11 & $\begin{array}{l}F C=1.18 \\
\operatorname{LogFC}=0.24 \\
p=0.12\end{array}$ & $\begin{array}{l}F C=-1.03 \\
\operatorname{LogFC}=-0.04 \\
p=0.59\end{array}$ & $\begin{array}{l}F C=1.39 \\
4 \operatorname{LogFC}=0.47 \\
p=0.04\end{array}$ & NA & $\begin{array}{l}F C=-1.1 \\
\operatorname{LogFC}=-0.13 \\
p=0.01\end{array}$ & $\begin{array}{l}F C=-1.15 \\
\log F C=-0.2 \\
p=0.37\end{array}$ & $\begin{array}{l}F C=-1.1 \\
\operatorname{LogFC}=-0.13 \\
p=0.57\end{array}$ & $\begin{array}{l}F C=-1.04 \\
\log F C=-0.05 \\
p=0.68\end{array}$ & $\begin{array}{l}F C=1 \text { LogFC } \\
=0 p=0.99\end{array}$ & $\begin{array}{l}F C=1.01 \\
\log F C=0.01 \\
p=0.94\end{array}$ & $\begin{array}{l}F C=1.12 \\
\log F C=0.16 p \\
=0.2\end{array}$ & A & $\begin{array}{l}F C=-1.08 \\
\operatorname{LogFC}=-0.11 \\
p=0.16\end{array}$ \\
\hline MAPK4 & 3 & 9 & $\begin{array}{l}F C=-1.05 \\
\log F C=-0.0 \\
p=0.75\end{array}$ & $\begin{array}{l}F C=1.04 \\
\operatorname{LogFC}=0.06 \\
p=0.33\end{array}$ & $\begin{array}{l}F C=2.93 \\
\log F C=1.55 \\
p=0\end{array}$ & $\begin{array}{l}F C=1.01 \\
\log F C=0.02 \\
p=0.45\end{array}$ & $\begin{array}{l}F C=-1.05 \\
\log F C=-0.07 \\
p=0.09\end{array}$ & $\begin{array}{l}F C=1.48 \\
\log F C=0.56 \\
p=0.15\end{array}$ & $\begin{array}{l}F C=1.18 \\
\operatorname{LogFC}=0.24 \\
p=0.55\end{array}$ & NA & NA & NA & NA & $\begin{array}{l}F C=1.01 \\
\operatorname{LogFC}=0.02 \\
p=0.51\end{array}$ & $\begin{array}{l}F C=-1.04 \\
\log F=-0.06 \\
p=0.52\end{array}$ \\
\hline MEF2C & 7 & 13 & $\begin{array}{l}F C=1.36 \\
\log F=0.44 \\
p=0.13\end{array}$ & $\begin{array}{l}F C=1.2 \\
\operatorname{LogFC}=0.26 \\
p=0.3\end{array}$ & $\begin{array}{l}F C=8.99 \\
\log F C=3.17 \\
p=0\end{array}$ & $\begin{array}{l}F C=-1.01 \\
\log F C=-0.02 \\
p=0.36\end{array}$ & $\begin{array}{l}F C=-1.01 \\
\log F C=-0.02 \\
p=0.42\end{array}$ & $\begin{array}{l}F C=1.2 \\
\operatorname{LogFC}=0.26 \\
p=0.37\end{array}$ & $\begin{array}{l}F C=-1.12 \\
\operatorname{LogFC}=-0.16 \\
p=0.6\end{array}$ & $\begin{array}{l}F C=1.12 \\
\operatorname{LogFC}=0.16 p \\
=0.43\end{array}$ & $\begin{array}{l}F C=-1.18 \\
\operatorname{LogFC}=- \\
0.24 p=0.25\end{array}$ & $\begin{array}{l}F C=-1.08 \\
\log F C=-0.12 \\
p=0.53\end{array}$ & $\begin{array}{l}F C=1.17 \\
\log F C=0.22 p \\
=0.24\end{array}$ & $\begin{array}{l}F C=1 \text { LogFC } \\
=0 p=0.97\end{array}$ & $\begin{array}{l}F C=1.57 \\
\operatorname{LogFC}=0.65 \\
p=0.18\end{array}$ \\
\hline
\end{tabular}




\begin{tabular}{|c|c|c|c|c|c|c|c|c|c|c|c|c|c|c|c|}
\hline NPAS4 & 4 & 5 & NA & $\begin{array}{l}F C=1.15 \\
\log F C=0.2 p \\
=0.03\end{array}$ & $\begin{array}{l}F C=2.53 \\
\log F=1.34 \\
p=0.03\end{array}$ & 4 NA & NA & $\begin{array}{l}F C=-1.23 \\
\log F C=-0.3 \\
p=0.31\end{array}$ & $\begin{array}{l}F C=1.08 \\
\log F C=0.12 \\
p=0.75\end{array}$ & NA & NA & NA & NA & NA & $\begin{array}{l}F C=-1.32 \\
\log F C=-0.4 \\
p=0.01\end{array}$ \\
\hline NPTX2 & 7 & 12 & NA & $\begin{array}{l}F C=-1.01 \\
\log F C=-0.02\end{array}$ & $\begin{array}{l}F C=-1.6 \\
2 \log F C=-\end{array}$ & $\begin{array}{l}F C=-1.2 \\
\log F C=-0.27\end{array}$ & $\begin{array}{l}F C=-1.23 \\
\log F C=-0.3\end{array}$ & $\begin{array}{l}F C=1.21 \\
\log F C=0.27\end{array}$ & $\begin{array}{l}F C=-1.21 \\
\log F C=-0.28\end{array}$ & $\begin{array}{l}F C=-1.07 \\
\log F C=-0.1 p\end{array}$ & $\begin{array}{l}F C=-1.28 \\
\log F C=-\end{array}$ & $\begin{array}{l}F C=-1.37 \\
\log F C=-0.45\end{array}$ & $\begin{array}{l}F C=-1.11 \\
\log F C=-0.15\end{array}$ & $\begin{array}{l}F C=-1.08 \\
\log F C=-0.11\end{array}$ & $\begin{array}{l}F C=-1.06 \\
\log F C=-0.08\end{array}$ \\
\hline & & & & $\begin{array}{l}p=0.84 \\
F C=1.06\end{array}$ & $\begin{array}{l}0.68 p=0.09 \\
F C=-3.23\end{array}$ & $\begin{array}{l}9 p=0 \\
F C=-\end{array}$ & $\begin{array}{l}p=0 \\
F C=-1.27\end{array}$ & $\begin{array}{l}p=0.53 \\
F C=1.06\end{array}$ & $\begin{array}{l}p=0.51 \\
F C=1.54\end{array}$ & $\begin{array}{l}=0.67 \\
F C=1.27\end{array}$ & $\begin{array}{l}0.35 p=0.28 \\
F C=-1.19\end{array}$ & $\begin{array}{l}p=0.27 \\
F C=1.11\end{array}$ & $\begin{array}{l}p=0.73 \\
F C=1.11\end{array}$ & $\begin{array}{l}p=0.15 \\
F C=-1.05\end{array}$ & $\begin{array}{l}p=0.41 \\
F C=-1.03\end{array}$ \\
\hline NR4A2 & 6 & 12 & NA & $\begin{array}{l}\operatorname{LogFC}=0.09 \\
p=0.33\end{array}$ & $\begin{array}{l}\operatorname{LogFC}=- \\
1.69 p=0.02\end{array}$ & $\begin{array}{l}\log F C=-0.3 p \\
2=0\end{array}$ & $\begin{array}{l}\log F C=-0.35 \\
p=0.13\end{array}$ & $\begin{array}{l}\log F C=0.09 \\
p=0.83\end{array}$ & $\begin{array}{l}\operatorname{LogFC}=0.62 \\
p=0.17\end{array}$ & $\begin{array}{l}\log F C=0.35 p \\
=0.16\end{array}$ & $\begin{array}{l}0 \operatorname{LogFC}=- \\
0.25 p=0.45\end{array}$ & $\begin{array}{l}\operatorname{LogFC}=0.15 \\
p=0.57\end{array}$ & $\begin{array}{l}\log F C=0.15 p \\
=0.55\end{array}$ & $\begin{array}{l}\operatorname{LogFC}=-0.08 \\
p=0.09\end{array}$ & $\begin{array}{l}\operatorname{LogFC}=-0.04 \\
p=0.79\end{array}$ \\
\hline OSBPL6 & 3 & 12 & $\begin{array}{l}F C=1.07 \\
\operatorname{LogFC}=0.1 p \\
=0.65\end{array}$ & $\begin{array}{l}F C=-1.05 \\
\operatorname{LogFC}=-0.07 \\
p=0.3\end{array}$ & $\begin{array}{l}F C=1.18 \\
7 \log F C=0.24 \\
p=0.33\end{array}$ & 4 NA & $\begin{array}{l}F C=-1.06 \\
\log F C=-0.08 \\
p=0.06\end{array}$ & $\begin{array}{l}F C=1.01 \\
\log F C=0.02 \\
p=0.87\end{array}$ & $\begin{array}{l}F C=-1.07 \\
\operatorname{LogFC}=-0.1 \\
p=0.43\end{array}$ & $\begin{array}{l}F C=-1.08 \\
\log F C=-0.11 \\
p=0.46\end{array}$ & $\begin{array}{l}F C=1.09 \\
\operatorname{LogFC}=0.13 \\
p=0.39\end{array}$ & $\begin{array}{l}F C=1.25 \\
\operatorname{LogFC}=0.33 \\
p=0.06\end{array}$ & $\begin{array}{l}F C=1.43 \\
\log F C=0.52 p \\
=0\end{array}$ & $\begin{array}{l}F C=-1.09 \\
\operatorname{LogFC}=-0.12 \\
p=0.09\end{array}$ & $\begin{array}{l}F C=1.09 \\
\log F C=0.12 \\
p=0.41\end{array}$ \\
\hline OSBPL9 & 2 & 13 & $\begin{array}{l}F C=1.02 \\
\log F C=0.03 \\
p=0.79\end{array}$ & $\begin{array}{l}F C=-1.06 \\
\operatorname{LogFC}=-0.09 \\
p=0.33\end{array}$ & $\begin{array}{l}F C=-1.52 \\
9 \log F C=-0.6 \\
p=0.02\end{array}$ & $\begin{array}{l}F C=1.01 \\
\log F C=0.02 \\
p=0.35\end{array}$ & $\begin{array}{l}F C=1.02 \\
\log F C=0.04 \\
p=0.4\end{array}$ & $\begin{array}{l}F C=-1.04 \\
\operatorname{LogFC}=-0.05 \\
p=0.4\end{array}$ & $\begin{array}{l}F C=-1.03 \\
\operatorname{LogFC}=-0.05 \\
p=0.49\end{array}$ & $\begin{array}{l}F C=-1.12 \\
\log F C=-0.17 \\
p=0.15\end{array}$ & $\begin{array}{l}F C=1.17 \\
\operatorname{LogFC}=0.23 \\
p=0.29\end{array}$ & $\begin{array}{l}F C=-1.05 \\
\operatorname{LogFC}=-0.06 \\
p=0.6\end{array}$ & $\begin{array}{l}F C=-1.12 \\
\log F C=-0.16 \\
p=0.08\end{array}$ & $\begin{array}{l}F C=1.03 \\
\operatorname{LogFC}=0.04 \\
p=0.38\end{array}$ & $\begin{array}{l}F C=-1.03 \\
\operatorname{LogFC}=-0.04 \\
p=0.75\end{array}$ \\
\hline $\mathrm{PCDH} 8$ & 4 & 14 & $\begin{array}{l}F C=1.08 \\
\log F=0.12 \\
p=0.41\end{array}$ & $\begin{array}{l}F C=1 \operatorname{LogFC} \\
=0 p=1\end{array}$ & $\begin{array}{l}F C=-1.41 \\
\operatorname{LogFC}=- \\
0.49 p=0.15\end{array}$ & $\begin{array}{l}F C=-1.01 \\
\log F C=-0.02 \\
5 p=0.63\end{array}$ & $\begin{array}{l}F C=-1 \log F C \\
=0 p=0.96\end{array}$ & $\begin{array}{l}F C=1.16 \\
\log F C=0.22 \\
p=0.5\end{array}$ & $\begin{array}{l}F C=1.11 \\
\log F C=0.15 \\
p=0.64\end{array}$ & $\begin{array}{l}F C=1.48 \\
\log F C=0.57 p \\
=0.04\end{array}$ & $\begin{array}{l}F C=-1.04 \\
\operatorname{LogFC}=- \\
0.06 p=0.8\end{array}$ & $\begin{array}{l}F C=1.11 \\
\operatorname{LogFC}=0.15 \\
p=0.59\end{array}$ & $\begin{array}{l}F C=1.1 \log F C \\
=0.14 p= \\
0.59\end{array}$ & $\begin{array}{l}F C=1.01 \\
\log F C=0.02 \\
p=0.82\end{array}$ & $\begin{array}{l}F C=1.05 \\
\log C=0.07 \\
p=0.5\end{array}$ \\
\hline PER1 & 4 & 13 & $\begin{array}{l}F C=1.03 \\
\log F C=0.04 \\
p=0.82\end{array}$ & $\begin{array}{l}F C=1.15 \\
\operatorname{LogFC}=0.2 p \\
=0.13\end{array}$ & $\begin{array}{l}F C=1.2 \\
\log F C=0.26 \\
p=0.43\end{array}$ & $\begin{array}{l}F C=1.05 \\
\operatorname{LogFC}=0.06 \\
p=0.02\end{array}$ & $\begin{array}{l}F C=1.06 \\
\log F C=0.09 \\
p=0.05\end{array}$ & $\begin{array}{l}F C=-1.08 \\
\log F C=-0.12 \\
p=0.56\end{array}$ & $\begin{array}{l}F C=1 \text { LogFC } \\
=0 p=0.99\end{array}$ & $\begin{array}{l}F C=1.02 \\
\log F C=0.03 p \\
=0.76\end{array}$ & $\begin{array}{l}F C=1.01 \\
\operatorname{LogFC}=0.02 \\
p=0.91\end{array}$ & $\begin{array}{l}F C=-1 \log F C \\
=0 p=0.99\end{array}$ & $\begin{array}{l}F C=-1.1 \\
\log F C=-0.14 \\
p=0.19\end{array}$ & $\begin{array}{l}F C=1.05 \\
\operatorname{LogFC}=0.07 \\
p=0.14\end{array}$ & $\begin{array}{l}F C=-1.12 \\
\operatorname{LogFC}=-0.17 \\
p=0.12\end{array}$ \\
\hline PHF21B & 2 & 8 & $\begin{array}{l}F C=1.08 \\
\operatorname{LogFC}=0.11 \\
p=0.42\end{array}$ & $\begin{array}{l}F C=1.07 \\
\log F C=0.09 \\
p=0.22\end{array}$ & $\begin{array}{l}F C=-1.48 \\
\operatorname{LogFC}=- \\
0.57 p=0.02\end{array}$ & ${ }_{2}^{N A}$ & $\begin{array}{l}F C=-1.03 \\
\log F C=-0.04 \\
p=0.28\end{array}$ & $\begin{array}{l}F C=-1.1 \\
\operatorname{LogFC}=-0.14 \\
p=0.44\end{array}$ & $\begin{array}{l}F C=1.07 \\
\log F C=0.09 \\
p=0.61\end{array}$ & NA & NA & NA & NA & NA & $\begin{array}{l}F C=-1.04 \\
\log F C=-0.06 \\
p=0.56\end{array}$ \\
\hline PLK2 & 4 & 12 & NA & $\begin{array}{l}F C=-1.03 \\
\log F C=-0.05\end{array}$ & $\begin{array}{l}F C=-1.09 \\
5 \log F C=-\end{array}$ & $\begin{array}{l}F C=-1.03 \\
\log F C=-0.05\end{array}$ & $\begin{array}{l}F C=-1.04 \\
\log F C=-0.06\end{array}$ & $\begin{array}{l}F C=-1.23 \\
\log F C=-0.3\end{array}$ & $\begin{array}{l}F C=-1.08 \\
\log F C=-0.11\end{array}$ & $\begin{array}{l}F C=1.4 \log F C \\
=0.48 p=\end{array}$ & $\begin{array}{c}\mathrm{FC}=-1.08 \\
\log F C=-\end{array}$ & $\begin{array}{l}F C=-1.06 \\
\log F C=-0.08\end{array}$ & $\begin{array}{l}F C=-1.1 \\
\log F C=-0.14\end{array}$ & $\begin{array}{l}F C=-1.01 \\
\log F C=-0.02\end{array}$ & $\begin{array}{l}F C=1.4 \\
\log F C=0.48\end{array}$ \\
\hline & & & & $p=0.7$ & $0.12 p=0.55$ & $p=0.13$ & $p=0.05$ & $p=0.17$ & $p=0.62$ & 0.03 & $0.12 p=0.59$ & $p=0.61$ & $p=0.44$ & $p=0.8$ & $p=0.19$ \\
\hline PROX1 & 5 & 13 & NA & $\begin{array}{l}F C=1.09 \\
\log F C=0.13 \\
p=0.15\end{array}$ & $\begin{array}{l}F C=1.84 \\
\log F C=0.88 \\
p=0.04\end{array}$ & $\begin{array}{l}F C=1.02 \\
\operatorname{LogFC}=0.03 \\
p=0.38\end{array}$ & $\begin{array}{l}F C=1.07 \\
\log F C=0.09 \\
p=0.01\end{array}$ & $\begin{array}{l}F C=-1.01 \\
\log F C=-0.01 \\
p=0.96\end{array}$ & $\begin{array}{l}F C=1.13 \\
\operatorname{LogFC}=0.18 \\
p=0.54\end{array}$ & $\begin{array}{l}F C=-1.53 \\
\log F C=-0.62 \\
p=0.06\end{array}$ & $\begin{array}{l}F C=-1.03 \\
\operatorname{LogFC}=- \\
0.05 p=0.83\end{array}$ & $\begin{array}{l}F C=1.16 \\
\operatorname{LogFC}=0.22 \\
p=0.39\end{array}$ & $\begin{array}{l}F C=1.11 \\
\log F C=0.14 p \\
=0.57\end{array}$ & $\begin{array}{l}F C=1.03 \\
\operatorname{LogFC}=0.04 \\
p=0.08\end{array}$ & $\begin{array}{l}F C=-1.14 \\
\operatorname{LogFC}=-0.19 \\
p=0.05\end{array}$ \\
\hline PSMB5 & 7 & 14 & $\begin{array}{l}F C=2.73 \\
\operatorname{LogFC}=1.45 \\
p=0\end{array}$ & $\begin{array}{l}F C=1.18 \\
\log F C=0.24 \\
p=0.07\end{array}$ & $\begin{array}{l}F C=-1.22 \\
\operatorname{LogFC}=- \\
0.29 p=0.34\end{array}$ & $\begin{array}{l}F C=-1.03 \\
\log F C=-0.05 \\
4 p=0.01\end{array}$ & $\begin{array}{l}F C=-1.05 \\
\log F C=-0.07 \\
p=0\end{array}$ & $\begin{array}{l}F C=1 \operatorname{LogFC} \\
=0 p=0.98\end{array}$ & $\begin{array}{l}F C=-1.01 \\
\log F C=-0.02 \\
p=0.84\end{array}$ & $\begin{array}{l}F C=1.06 \\
\operatorname{LogFC}=0.08 p \\
=0.48\end{array}$ & $\begin{array}{l}F C=1.12 \\
\operatorname{LogFC}=0.16 \\
p=0.34\end{array}$ & $\begin{array}{l}F C=1.1 \\
\operatorname{LogFC}=0.13 \\
p=0.28\end{array}$ & $\begin{array}{l}F C=1.06 \\
\operatorname{LogFC}=0.08 p \\
=0.44\end{array}$ & $\begin{array}{l}F C=-1.1 \\
\operatorname{LogFC}=-0.14 \\
p=0.1\end{array}$ & $\begin{array}{l}F C=1.18 \\
\log F C=0.24\end{array}$ \\
\hline RASL10A & 4 & 11 & $\begin{array}{l}F C=-1.39 \\
\operatorname{LogFC}=-0.47 \\
p=0.03\end{array}$ & $\begin{array}{l}F C=1.04 \\
\log F C=0.06 \\
p=0.53\end{array}$ & NA & $\begin{array}{l}F C=-1.09 \\
\log F C=-0.13 \\
p=0\end{array}$ & $\begin{array}{l}F C=-1.16 \\
\log F C=-0.22 \\
p=0.02\end{array}$ & $\begin{array}{l}F C=1.08 \\
\log C=0.11 \\
p=0.76\end{array}$ & $\begin{array}{l}F C=1.21 \\
\operatorname{LogFC}=0.28 \\
p=0.55\end{array}$ & $\begin{array}{l}F C=1.12 \\
\operatorname{LogFC}=0.16 p \\
=0.45\end{array}$ & $\begin{array}{l}F C=1.1 \\
\log C=0.13 \\
p=0.51\end{array}$ & $\begin{array}{l}F C=-1.07 \\
\log F=-0.09 \\
p=0.75\end{array}$ & $\begin{array}{l}F C=1.14 \\
\operatorname{LogFC}=0.19 p \\
=0.37\end{array}$ & NA & $\begin{array}{l}F C=1.02 \\
\log F C=0.03 \\
p=0.74\end{array}$ \\
\hline RASL11A & 1 & 6 & $\begin{array}{l}F C=-2.24 \\
\operatorname{LogFC}=-1.17 \\
p=0\end{array}$ & $\begin{array}{l}F C=-1.03 \\
\operatorname{LogFC}=-0.04 \\
p=0.64\end{array}$ & & NA & $\begin{array}{l}F C=-1.07 \\
\operatorname{LogFC}=-0.09 \\
p=0.06\end{array}$ & $\begin{array}{l}F C=1.01 \\
\operatorname{LogFC}=0.01 \\
p=0.97\end{array}$ & $\begin{array}{l}F C=1.11 \\
\operatorname{LogFC}=0.15 \\
p=0.6\end{array}$ & NA & NA & NA & NA & NA & $\begin{array}{l}F C=-1.13 \\
\operatorname{LogFC}=-0.17 \\
p=0.14\end{array}$ \\
\hline RPL7A & 4 & 12 & $\begin{array}{l}F C=-1.07 \\
\operatorname{LogFC}=-0.09\end{array}$ & $\begin{array}{l}F C=1.08 \\
\log F C=0.11\end{array}$ & $\begin{array}{l}F C=-1.46 \\
\operatorname{LogFC}=-\end{array}$ & NA & $\begin{array}{l}F C=1.01 \\
\log C=0.02\end{array}$ & $\begin{array}{l}F C=-1.04 \\
\log F C=-0.05\end{array}$ & $\begin{array}{l}F C=-1.05 \\
\log F C=-0.07\end{array}$ & $\begin{array}{l}F C=1.19 \\
\log F C=0.25 p\end{array}$ & $\begin{array}{l}F C=1.29 \\
\log C=0.36\end{array}$ & $\begin{array}{l}F C=1.03 \\
\log F C=0.04\end{array}$ & $\begin{array}{l}F C=1.05 \\
\operatorname{LogFC}=0.07 p\end{array}$ & $\begin{array}{l}F C=-1.03 \\
\log F C=-0.04\end{array}$ & $\begin{array}{l}F C=1.34 \\
\log F C=0.42\end{array}$ \\
\hline & & & $p=0.29$ & $p=0.21$ & $0.55 p=0.03$ & & $p=0.34$ & $p=0.61$ & $p=0.53$ & $=0.14$ & $p=0.27$ & $p=0.72$ & $=0.38$ & $p=0.38$ & $p=0.11$ \\
\hline
\end{tabular}




\begin{tabular}{|c|c|c|c|c|c|c|c|c|c|c|c|c|c|c|c|}
\hline & & & $F C=-1.13$ & 1.06 & $\mathrm{FC}=$ & & 66 & & & $=1.44$ & $F C=-1.06$ & $\mathrm{FC}=1.24$ & $\mathrm{FC}=1.1 \mathrm{Log} F \mathrm{C}$ & $F C=-1.03$ & $\mathrm{FC}=$ \\
\hline RTN4RL1 & 4 & 10 & $\begin{array}{l}\operatorname{LogFC}=-0.18 \\
p=0.5\end{array}$ & $\begin{array}{l}3 \operatorname{LogFC}=0.09 \\
p=0.31\end{array}$ & $\begin{array}{l}\log F C=0.47 \\
p=0.18\end{array}$ & NA & $\begin{array}{l}\log F C=-0.08 \\
p=0\end{array}$ & NA & NA & $\begin{array}{l}\log F C=0.53 p \\
=0.01\end{array}$ & $\begin{aligned} 0 \operatorname{LogFC} & =- \\
0.09 p & =0.59\end{aligned}$ & $\begin{array}{l}\operatorname{LogFC}=0.31 \\
p=0.08\end{array}$ & $\begin{array}{l}=0.14 p= \\
0.35\end{array}$ & $\begin{array}{l}\log F C=-0.05 \\
p=0.73\end{array}$ & $\begin{array}{l}\log F C=0.11 \\
p=0.48\end{array}$ \\
\hline SERTAD1 & 4 & 12 & $\begin{array}{l}F C=1.08 \\
\operatorname{LogFC}=0.11 \\
p=0.6\end{array}$ & $\begin{array}{l}F C=-1.01 \\
\operatorname{LogFC}=-0.01 \\
p=0.94\end{array}$ & $\begin{array}{c}F C=-1.74 \\
1 \operatorname{LogFC}=-0.8 \\
p=0.09\end{array}$ & NA & $\begin{array}{l}F C=1.04 \\
\log F C=0.06 \\
p=0.24\end{array}$ & $\begin{array}{l}F C=-1.07 \\
\log F C=-0.1 \\
p=0.62\end{array}$ & $\begin{array}{l}F C=1.14 \\
\operatorname{LogFC}=0.18 \\
p=0.38\end{array}$ & $\begin{array}{l}F C=-1.16 \\
\log F C=-0.21 \\
p=0.35\end{array}$ & $\begin{array}{l}F C=-1 \log F C \\
=-0.01 p= \\
0.98\end{array}$ & $\begin{array}{l}\text { CFC }=-1.4 \\
\operatorname{LogFC}=-0.49 \\
p=0.09\end{array}$ & $\begin{array}{l}F C=-1.27 \\
\log F C=-0.35 \\
p=0.21\end{array}$ & $\begin{array}{l}F C=-1.02 \\
\operatorname{LogFC}=-0.03 \\
p=0.48\end{array}$ & $\begin{array}{l}F C=-1.03 \\
\log F C=-0.04 \\
p=0.78\end{array}$ \\
\hline SLC17A6 & 6 & 12 & NA & $\begin{array}{l}F C=-1.01 \\
\operatorname{LogFC}=-0.02 \\
p=0.87\end{array}$ & $\begin{array}{l}F C=-6.58 \\
2 \operatorname{LogFC}=- \\
2.72 p=0\end{array}$ & $\begin{array}{l}F C=-1.11 \\
\log F C=-0.15 \\
p=0\end{array}$ & $\begin{array}{l}F C=-1.07 \\
\operatorname{LogFC}=-0.1 \\
p=0.02\end{array}$ & $\begin{array}{l}F C=-1.08 \\
\operatorname{LogFC}=-0.11 \\
p=0.8\end{array}$ & $\begin{array}{l}\mathrm{FC}=1.26 \\
1 \operatorname{LogFC}=0.33 \\
p=0.51\end{array}$ & $\begin{array}{l}F C=-1.06 \\
\log F C=-0.09 \\
p=0.77\end{array}$ & $\begin{array}{l}F C=-1.41 \\
\log F C=-0.5 \\
p=0.01\end{array}$ & $\begin{array}{l}F C=-1.19 \\
\operatorname{LogFC}=-0.25 \\
p=0.21\end{array}$ & $\begin{array}{l}F C=1.14 \\
\operatorname{LogFC}=0.19 p \\
=0.44\end{array}$ & $\begin{array}{l}F C=-1.02 \\
\log F C=-0.03 \\
p=0.56\end{array}$ & $\begin{array}{l}F C=-1.03 \\
\log F C=-0.04 \\
p=0.72\end{array}$ \\
\hline SLC25A25 & 3 & 11 & $\begin{array}{l}F C=1.22 \\
\operatorname{LogFC}=0.29 \\
p=0.31\end{array}$ & $\begin{array}{l}F C=-1.07 \\
\operatorname{LogFC}=-0.1 \\
p=0.21\end{array}$ & $\begin{array}{l}F C=1.77 \\
\log F C=0.82 \\
p=0.01\end{array}$ & NA & $\begin{array}{l}F C=-1.07 \\
\log F C=-0.09 \\
p=0.04\end{array}$ & $\begin{array}{l}F C=-1.1 \\
\log F C=-0.14 \\
p=0.24\end{array}$ & $\begin{array}{l}F C=-1.08 \\
4 \log F C=-0.11 \\
p=0.38\end{array}$ & $\begin{array}{l}F C=-1.01 \\
\log F C=-0.02 \\
p=0.89\end{array}$ & $\begin{array}{l}F C=1.11 \\
\operatorname{LogFC}=0.15 \\
p=0.34\end{array}$ & $\begin{array}{l}F C=1.06 \\
\operatorname{LogFC}=0.09 \\
p=0.39\end{array}$ & $\begin{array}{l}F C=1.03 \\
\operatorname{LogFC}=0.05 p \\
=0.83\end{array}$ & NA & $\begin{array}{l}F C=-1.01 \\
\operatorname{LogFC}=-0.01 \\
p=0.92\end{array}$ \\
\hline SLC30A3 & 3 & 7 & NA & $\begin{array}{l}F C=1.03 \\
\operatorname{LogFC}=0.04 \\
p=0.58\end{array}$ & NA & $\begin{array}{l}F C=-1.08 \\
\operatorname{LogFC}=-0.11 \\
p=0\end{array}$ & $\begin{array}{l}F C=-1.02 \\
\log F C=-0.02 \\
p=0.6\end{array}$ & $\begin{array}{l}F C=-1.3 \\
\log F C=-0.38 \\
p=0.32\end{array}$ & $\begin{array}{l}F C=1.15 \\
3 \operatorname{LogFC}=0.2 p \\
=0.63\end{array}$ & NA & NA & NA & NA & $\begin{array}{l}F C=-1.09 \\
\operatorname{LogFC}=-0.13 \\
p=0.16\end{array}$ & $\begin{array}{l}F C=1.01 \\
\log F C=0.02 \\
p=0.88\end{array}$ \\
\hline SOX11 & 4 & 12 & NA & $\begin{array}{l}F C=-1.14 \\
\operatorname{LogFC}=-0.18 \\
p=0.16\end{array}$ & $\begin{array}{l}F C=2.81 \\
8 \operatorname{LogFC}=1.49 \\
p=0\end{array}$ & $\begin{array}{l}F C=1 \operatorname{LogFC} \\
=0.01 p= \\
0.79\end{array}$ & $\begin{array}{l}F C=1.02 \\
\log F C=0.03 \\
p=0.43\end{array}$ & $\begin{array}{l}F C=1.24 \\
\log F C=0.31 \\
p=0.05\end{array}$ & $\begin{array}{l}F C=1.14 \\
\operatorname{LogFC}=0.19 \\
p=0.24\end{array}$ & $\begin{array}{l}F C=1.08 \\
\log F C=0.12 p \\
=0.67\end{array}$ & $\begin{array}{l}F C=1.08 \\
\operatorname{LogFC}=0.11 \\
p=0.72\end{array}$ & $\begin{array}{l}F C=-1.2 \\
\operatorname{LogFC}=-0.26 \\
p=0.19\end{array}$ & $\begin{array}{l}F C=-1.26 \\
\log F C=-0.33 \\
p=0.15\end{array}$ & $\begin{array}{l}F C=1.01 \\
\operatorname{LogFC}=0.01 \\
p=0.43\end{array}$ & $\begin{array}{l}F C=1.07 \\
\operatorname{LogFC}=0.1 p \\
=0.41\end{array}$ \\
\hline SSTR2 & 6 & 12 & NA & $\begin{array}{l}F C=-1.17 \\
\operatorname{LogFC}=-0.23 \\
p=0.23\end{array}$ & $\begin{array}{l}F C=-1.55 \\
3 \operatorname{LogFC}=- \\
0.63 p=0.1\end{array}$ & $\begin{array}{l}F C=-1.02 \\
\log F C=-0.03 \\
p=0.31\end{array}$ & $\begin{array}{l}F C=-1.08 \\
\operatorname{LogFC}=-0.11 \\
p=0\end{array}$ & $\begin{array}{l}F C=1.02 \\
\log F C=0.03 \\
p=0.91\end{array}$ & $\begin{array}{l}F C=1.07 \\
\log F C=0.09 \\
p=0.73\end{array}$ & $\begin{array}{l}F C=1.04 \\
\log F C=0.05 p \\
=0.81\end{array}$ & $\begin{array}{l}F C=1.15 \\
\operatorname{LogFC}=0.2 p \\
=0.35\end{array}$ & $\begin{array}{l}F C=1.24 \\
\operatorname{LogFC}=0.31 \\
p=0.23\end{array}$ & $\begin{array}{l}F C=1.36 \\
\log F C=0.45 p \\
=0.01\end{array}$ & $\begin{array}{l}F C=-1.03 \\
\operatorname{LogFC}=-0.04 \\
p=0.3\end{array}$ & $\begin{array}{l}F C=1.13 \\
\operatorname{LogFC}=0.18 \\
p=0.12\end{array}$ \\
\hline TANC1 & 7 & 12 & $\begin{array}{l}F C=1.09 \\
\operatorname{LogFC}=0.13 \\
p=0.6\end{array}$ & $\begin{array}{l}F C=1.04 \\
\operatorname{LogFC}=0.06 \\
p=0.43\end{array}$ & $\begin{array}{l}F C=-2.35 \\
\operatorname{LogFC}=- \\
1.24 p=0\end{array}$ & NA & $\begin{array}{l}F C=1.02 \\
\operatorname{LogFC}=0.03 \\
p=0.33\end{array}$ & $\begin{array}{l}F C=1.05 \\
\log C=0.07 \\
p=0.76\end{array}$ & $\begin{array}{l}F C=-1.17 \\
\log F C=-0.23 \\
p=0.35\end{array}$ & $\begin{array}{l}F C=-1.48 \\
\log F C=-0.57 \\
p=0.02\end{array}$ & $\begin{array}{l}F C=-1.2 \\
\operatorname{LogFC}=- \\
0.26 p=0.14\end{array}$ & $\begin{array}{l}F C=-1.2 \\
\operatorname{LogFC}=-0.27 \\
p=0.15\end{array}$ & $\begin{array}{l}F C=-1.32 \\
\operatorname{LogFC}=-0.4 p \\
=0.06\end{array}$ & NA & $\begin{array}{l}F C=-1.08 \\
\operatorname{LogFC}=-0.11 \\
p=0.2\end{array}$ \\
\hline TAX1BP1 & 5 & 14 & $\begin{array}{l}F C=1.11 \\
\operatorname{LogFC}=0.15 \\
p=0.44\end{array}$ & $\begin{array}{l}F C=-1.03 \\
\operatorname{LogFC}=-0.05 \\
p=0.79\end{array}$ & $\begin{array}{l}F C=-1.61 \\
5 \operatorname{LogFC}=- \\
0.69 p=0\end{array}$ & $\begin{array}{l}F C=-1.03 \\
\log F C=-0.05 \\
p=0.01\end{array}$ & $\begin{array}{l}F C=-1 \operatorname{LogFC} \\
=0 p=0.8\end{array}$ & $\begin{array}{l}F C=-1.06 \\
\log F C=-0.09 \\
p=0.14\end{array}$ & $\begin{array}{l}F C=-1.04 \\
\log F C=-0.05 \\
p=0.41\end{array}$ & $\begin{array}{l}F C=1.15 \\
\operatorname{LogFC}=0.2 p \\
=0.01\end{array}$ & $\begin{array}{l}F C=-1.03 \\
\operatorname{LogFC}=- \\
0.04 p=0.68\end{array}$ & $\begin{array}{l}F C=1.02 \\
\operatorname{LogFC}=0.03 \\
p=0.8\end{array}$ & $\begin{array}{l}F C=1.07 \\
\operatorname{LogFC}=0.1 p \\
=0.13\end{array}$ & $\begin{array}{l}F C=-1.04 \\
\operatorname{LogFC}=-0.05 \\
p=0.19\end{array}$ & $\begin{array}{l}F C=1.58 \\
\log F C=0.66 \\
p=0.1\end{array}$ \\
\hline TMEM198 & 4 & 11 & $\begin{array}{l}F C=2.4 \\
\operatorname{LogFC}=1.26 \\
p=0\end{array}$ & $\begin{array}{l}F C=-1.07 \\
\operatorname{LogFC}=-0.1 \\
p=0.24\end{array}$ & $\begin{array}{l}F C=1.7 \\
\operatorname{LogFC}=0.76 \\
p=0\end{array}$ & ¿NA & $\begin{array}{l}F C=-1.04 \\
\operatorname{LogFC}=-0.06 \\
p=0.06\end{array}$ & $\begin{array}{l}F C=1.02 \\
\log C=0.02 \\
p=0.83\end{array}$ & $\begin{array}{l}F C=-1.05 \\
\log F C=-0.07 \\
p=0.57\end{array}$ & $\begin{array}{l}F C=1.02 \\
\log F C=0.03 p \\
=0.85\end{array}$ & $\begin{array}{l}F C=-1.12 \\
\operatorname{LogFC}=- \\
0.16 p=0.22\end{array}$ & $\begin{array}{l}F C=1.16 \\
\operatorname{LogFC}=0.21 \\
p=0.08\end{array}$ & $\begin{array}{l}F C=1.16 \\
\operatorname{LogFC}=0.21 p \\
=0.05\end{array}$ & NA & $\begin{array}{l}F C=1.01 \\
\operatorname{LogFC}=0.02 \\
p=0.87\end{array}$ \\
\hline WFS1 & 4 & 14 & $\begin{array}{l}F C=1.08 \\
\operatorname{LogFC}=0.12 \\
p=0.35\end{array}$ & $\begin{array}{l}F C=-1.06 \\
\operatorname{LogFC}=-0.08 \\
p=0.26\end{array}$ & $\begin{array}{l}F C=-1.96 \\
8 \operatorname{LogFC}=- \\
0.97 p=0\end{array}$ & $\begin{array}{l}F C=1.08 \\
\log F C=0.12 \\
p=0\end{array}$ & $\begin{array}{l}F C=1.04 \\
\log F C=0.05 \\
p=0.37\end{array}$ & $\begin{array}{l}F C=-1.06 \\
\log F C=-0.09 \\
p=0.4\end{array}$ & $\begin{array}{l}F C=-1.02 \\
\operatorname{LogFC}=-0.03 \\
p=0.77\end{array}$ & $\begin{array}{l}F C=-1.08 \\
\operatorname{LogFC}=-0.1 p \\
=0.36\end{array}$ & $\begin{array}{l}F C=1.15 \\
\operatorname{LogFC}=0.2 p \\
=0.52\end{array}$ & $\begin{array}{l}F C=1.11 \\
\operatorname{LogFC}=0.15 \\
p=0.21\end{array}$ & $\begin{array}{l}F C=1.01 \\
\operatorname{LogFC}=0.01 p \\
=0.94\end{array}$ & $\begin{array}{l}F C=1.04 \\
\operatorname{LogFC}=0.05 \\
p=0.31\end{array}$ & $\begin{array}{l}F C=-1.12 \\
\operatorname{LogFC}=-0.16 \\
p=0.08\end{array}$ \\
\hline ZDHHC21 & 2 & 12 & $\begin{array}{l}F C=-1.01 \\
\log F C=-0.0 \\
p=0.95\end{array}$ & $\begin{array}{l}F C=-1.03 \\
\operatorname{LogFC}=-0 . C \\
p=0.63\end{array}$ & $\begin{array}{l}F C=1.02 \\
5 \log F C=0.03 \\
p=0.93\end{array}$ & NA & $\begin{array}{l}F C=-1 \operatorname{LogFC} \\
=0 p=0.9\end{array}$ & $\begin{array}{l}F C=1.01 \\
\log F C=0.02 \\
p=0.83\end{array}$ & $\begin{array}{l}F C=1.01 \\
\operatorname{LogFC}=0.01 \\
p=0.93\end{array}$ & $\begin{array}{l}F C=1.26 \\
\log F C=0.34 p \\
=0.01\end{array}$ & $\begin{array}{l}F C=-1.11 \\
\log F C=- \\
0.15 p=0.39\end{array}$ & $\begin{array}{l}F C=-1.05 \\
\log F C=-0.07 \\
p=0.69\end{array}$ & $\begin{array}{l}F C=-1.06 \\
\log F C=-0.08 \\
p=0.58\end{array}$ & $\begin{array}{l}F C=1.03 \\
\log F C=0.05 \\
p=0.11\end{array}$ & $\begin{array}{l}F C=1.32 \\
\log F C=0.4 p \\
=0.1\end{array}$ \\
\hline
\end{tabular}


Table 3. Statistics for microarray and qRT-PCR analyses

\begin{tabular}{|c|c|c|}
\hline Gene & Two way ANOVA results & $\begin{array}{l}\text { Post hoc comparison (Tukey's test) results } \\
\left(p<0.05,{ }^{* *} p<0.01,{ }^{* * *} p<0.001, * * * * p<0.0001\right)\end{array}$ \\
\hline $\begin{array}{l}\text { Gadd45b (M, } \\
\text { microarray) }\end{array}$ & $\begin{array}{l}\text { sig interaction of genotype } \& \text { treatment } F(1,12)=18.39, \\
p=0.0011\end{array}$ & WT vs WT ECS ***, WT ECS vs KO ECS *** \\
\hline Gadd45b (M, qRT PCR) & $\begin{array}{l}\text { sig interaction of genotype \& treatment } F(1,12)=12.55, \\
p=0.0041\end{array}$ & WT vs WT ECS ***, WT ECS vs KO ECS ** \\
\hline Gadd45b (F, qRT PCR) & $\begin{array}{l}\text { sig effect of genotype } F(1,14)=5.302, p=0.0372 ; \\
\text { sig effect of treatment } F(1,14)=15.80, p=0.0014\end{array}$ & WT vs WT ECS **, WT ECS vs KO ECS * \\
\hline $\begin{array}{l}\text { Gadd45g (M, } \\
\text { microarray) }\end{array}$ & $\begin{array}{l}\text { sig interaction of genotype \& treatment } F(1,12)=18.39 \\
p=0.0011\end{array}$ & WT vs WT ECS ***, WT ECS vs KO ECS ** \\
\hline Gadd45g (M, qRT PCR) & $\begin{array}{l}\text { sig interaction of genotype \& treatment } F(1,12)=9.875, \\
p=0.0085\end{array}$ & WT vs WT ECS ***, WT ECS vs KO ECS * \\
\hline Gadd45g (F, qRT PCR) & Not sig & $\mathrm{N} / \mathrm{A}$ \\
\hline Cdnk1a (M, microarray) & $\begin{array}{l}\text { sig interaction of genotype \& treatment } F(1,12)=7.316 \\
p=0.0191\end{array}$ & WT vs WT ECS ****, KO vs KO ECS *, WT ECS vs KO ECS * \\
\hline Cenpa ( $M$, microarray) & $\begin{array}{l}\text { sig interaction of genotype \& treatment } F(1,12)=263.1, \\
p<0.0001\end{array}$ & WT vs WT ECS $* * * *$, WT ECS vs KO ECS **** \\
\hline Cenpa (M, qRT PCR) & $\begin{array}{l}\text { sig interaction of genotype \& treatment } F(1,12)= \\
103.9, p<0.0001\end{array}$ & WT vs WT ECS ****, WT ECS vs KO ECS **** \\
\hline Cenpa (F, qRT PCR) & $\begin{array}{l}\text { sig interaction of genotype \& treatment } F(1,14)=68.28, \\
p<0.0001\end{array}$ & WT vs WT ECS ****, WT ECS vs KO ECS **** \\
\hline Fos (M, microarray) & $\begin{array}{l}\text { sig interaction of genotype \& treatment } F(1,12)=10.92, \\
p=0.0063\end{array}$ & WT vs WT ECS ****, KO vs KO ECS *, WT ECS vs KO ECS ** \\
\hline Fos (M, qRT PCR) & $\begin{array}{l}\text { sig interaction of genotype \& treatment } F(1,12)=5.808, \\
p=0.0329\end{array}$ & WT vs WT ECS **, WT ECS vs KO ECS * \\
\hline Fos (F, qRT PCR) & sig effect of treatment $F(1,14)=8.392, p=0.0117$ & WT vs WT ECS * \\
\hline Fosb (M, microarray) & $\begin{array}{l}\text { sig interaction of genotype \& treatment } F(1,12)=63.79, \\
p<0.0001\end{array}$ & WT vs WT ECS ****, WT ECS vs KO ECS **** \\
\hline Fosb (M, qRT PCR) & $\begin{array}{l}\text { sig interaction of genotype \& treatment } F(1,12)=14.01, \\
p=0.0028\end{array}$ & WT vs WT ECS ***, WT ECS vs KO ECS *** \\
\hline
\end{tabular}




\begin{tabular}{|c|c|c|}
\hline Fosb (F, qRT PCR) & $\begin{array}{l}\text { sig interaction of genotype \& treatment } F(1,14)=7.094, \\
p=0.0185\end{array}$ & WT vs WT ECS ***, WT ECS vs KO ECS ** \\
\hline Junb(M, microarray) & $\begin{array}{l}\text { sig interaction of genotype \& treatment } F(1,12)=18.22, \\
p=0.0011\end{array}$ & $\begin{array}{l}\text { WT vs WT ECS ****, KO vs KO ECS *, WT ECS vs KO ECS } \\
* * *\end{array}$ \\
\hline $\operatorname{Junb}(\mathrm{M}, \mathrm{qRT} P C R)$ & sig effect of treatment $F(1,12)=6.247, p=0.0280$ & posthoc comparisons NS \\
\hline $\operatorname{Junb}(F, q R T P C R)$ & $\begin{array}{l}\text { sig effect of treatment } F(1,14)=6.569, p=0.0225 ; \text { sig } \\
\text { effect of genotype } F(1,14)=4.608, p=0.0498\end{array}$ & posthoc comparisons NS \\
\hline Npas4(M, microarray) & $\begin{array}{l}\text { sig interaction of genotype \& treatment } F(1,12)=24.11, \\
p=0.0004\end{array}$ & WT vs WT ECS $* * * *$, WT ECS vs KO ECS *** \\
\hline Npas4(M, qRT PCR) & $\begin{array}{l}\text { sig interaction of genotype \& treatment } F(1,12)=8.37 \\
p=0.0135\end{array}$ & WT vs WT ECS **, WT ECS vs KO ECS ** \\
\hline Npas4 (F, qRT PCR) & $\begin{array}{l}\text { sig effect of treatment } F(1,14)=9.73 p=0.0075 \text {, sig } \\
\text { effect of genotype } F(1,14)=9.68, p=0.0077\end{array}$ & WT vs WT ECS *, WT ECS vs KO ECS * \\
\hline Nr4a2 (M, microarray) & $\begin{array}{l}\text { sig interaction of genotype \& treatment } F(1,12)=15.90, \\
p=0.0018\end{array}$ & WT vs WT ECS ***, WT ECS vs KO ECS *** \\
\hline $\mathrm{Nr} 4 \mathrm{a} 2$ (M, qRT PCR) & $\begin{array}{l}\text { sig interaction of genotype \& treatment } F(1,12)=7.050, \\
p=0.0210\end{array}$ & WT vs WT ECS ***, WT ECS vs KO ECS ** \\
\hline Nr4a2 (F, qRT PCR) & $\begin{array}{l}\text { sig interaction of genotype \& treatment } F(1,14)=5.230 \text {, } \\
p=0.0383\end{array}$ & WT vs WT ECS * \\
\hline Mef2c (M, microarray) & $\begin{array}{l}\text { sig interaction of genotype \& treatment } F(1,12)= \\
21.07, p=0.0006\end{array}$ & WT vs WT ECS ${ }^{* *}$, KO vs. WT ECS ${ }^{* *}$ \\
\hline Mef2c (M, qRT PCR) & $\begin{array}{l}\text { sig interaction of genotype \& treatment } F(1,12)=9.484, \\
p=0.0095\end{array}$ & posthoc comparisons NS \\
\hline Mef2c (F, qRT PCR) & Not sig & $\mathrm{N} / \mathrm{A}$ \\
\hline Calb2 (M, microarray) & sig effect of genotype $F(1,12)=48.99, p<0.0001$ & WT vs KO $\mathrm{KO}^{* * *}$, WT ECS vs. KO ECS ${ }^{* *}$ \\
\hline Calb2 (M, qRT PCR) & sig effect of genotype $F(1,12)=11, p=0.0061$ & posthoc comparisons NS \\
\hline Calb2 (F, qRT PCR) & Not sig & N/A \\
\hline
\end{tabular}

